\title{
Effects of bottom-layer hypoxia on abundances and depth distributions of organisms in Patuxent River, Chesapeake Bay
}

\author{
Julie E. Keister ${ }^{1, *}$, Edward D. Houde ${ }^{1}$, Denise L. Breitburg ${ }^{2}$ \\ ${ }^{1}$ University of Maryland, Center for Environmental Science, Chesapeake Biological Laboratory, PO Box 38, \\ Solomons, Maryland 20688, USA
}

${ }^{2}$ The Academy of Natural Sciences, Estuarine Research Center, 10545 Mackall Rd, St. Leonard, Maryland 20685, USA

\begin{abstract}
Oxygen depletion, seasonally common in bottom waters of many stratified aquatic systems, may have strong effects on abundances, distributions, and interactions among organisms, and therefore community dynamics. To examine effects of bottom-layer hypoxia on densities and vertical distributions in a stratified subestuary, fish larvae, their gelatinous predators, and copepod prey were surveyed near-surface, within the pycnocline, and near-bottom in the Patuxent River (Chesapeake Bay) under a range of near-bottom dissolved oxygen (DO) conditions. Overall abundances of fish larvae and copepod nauplii were lower throughout the water column when bottom-layer DO was low $\left(\leq 2 \mathrm{mg} \mathrm{DO}^{-1}\right)$. When bottom-layer DO was low $\left(\leq 2 \mathrm{mg} \mathrm{l}^{-1}\right)$, densities of naked goby larvae were less than one-third of those observed during high $\left(>2 \mathrm{mg} \mathrm{l}^{-1}\right)$ DO conditions, and overall density of copepod nauplii declined by $>50 \%$. Depth-distributions of several organisms also were affected by bottom-oxygen depletion: fish larvae, scyphomedusae, and copepods were much less common near the bottom when bottom-layer DO was low than when it was $>2 \mathrm{mg} \mathrm{l}^{-1}$. The ctenophore Mnemiopsis leidyi occurred in high densities at DO as low as $1.3 \mathrm{mg} \mathrm{l}^{-1}$, but was nearly absent at $<1 \mathrm{mg} \mathrm{l}^{-1}$. The results indicate the potential for substantial differences in organism interactions, especially predatorprey relationships, between times of high and low bottom-layer DO.
\end{abstract}

KEY WORDS: Hypoxia $\cdot$ Chesapeake Bay $\cdot$ Fish larvae $\cdot$ Naked goby $\cdot$ Anchovy $\cdot$ Jellyfish $\cdot$ Vertical distribution $\cdot$ Zooplankton

Resale or republication not permitted without written consent of the publisher

\section{INTRODUCTION}

Low dissolved oxygen concentrations occur in many aquatic habitats, including estuaries, lakes, fjords, and nearshore coastal areas. Oxygen depletion can affect communities in many ways, including limiting abundances of organisms through direct mortality and reducing the availability of suitable habitat. For example, decreased survival at low oxygen concentrations that commonly occur in Chesapeake Bay has been

\footnotetext{
${ }^{*}$ Present address: Oregon State University, Hatfield Marine Science Center, 2030 S. Marine Science Dr., Newport, Oregon 97365, USA. E-mail: julie.keister@noaa.gov
}

reported for many organisms, including larvae of the naked goby Gobiosoma bosc and the bay anchovy Anchoa mitchilli (Chesney \& Houde 1989, Breitburg 1994), striped bass Morone saxatilis (Coutant 1985, D. Miller as cited in Jordan et al. 1992), copepods (Roman et al. 1993), ctenophores Mnemiopsis leidyi, and the scyphomedusan Chrysaora quinquecirrha (E.D.H. unpubl. data).

Avoidance behaviors also result in low densities of mobile organisms in bottom layers with low dissolved oxygen. For example, during summer, adult striped bass are normally found in cool bottom-waters of reservoirs, but move vertically in stratified water columns to avoid dissolved oxygen (DO) concentrations below 2 to 
$3 \mathrm{mg} \mathrm{l}^{-1}$ (Coutant 1985). Nesting sites of naked gobies may be subject to influxes of low DO, forcing eggguarding adults from their nests (Breitburg 1992). Similarly, invertebrate species commonly inhabiting the benthos of freshwater lakes move toward the surface to avoid hypoxic bottom water (Kolar \& Rahel 1993).

We surveyed densities and vertical distributions of fish larvae, their predators and their prey in the Patuxent River, a tributary of Chesapeake Bay, during summer when episodes of bottom-layer hypoxia were common. Chesapeake Bay is a partially mixed estuary that develops strong thermohaline stratification in late spring and summer. In many areas of the Chesapeake Bay system, subpycnocline waters commonly experience episodes of hypoxia and anoxia which may last from hours to weeks (Taft et al. 1980, Sanford et al. 1990). The extent of oxygen depletion apparently has increased due to anthropogenic nutrient loading (Mackiernan et al. 1983, Officer et al. 1984, Cooper \& Brush 1991).

During the summer, Chesapeake Bay and its tributaries, including the Patuxent River, support large populations of naked goby and bay anchovy larvae (Dovel 1971, Olney 1983, Shenker et al. 1983). Naked goby and bay anchovy larvae prey primarily on copepods (Detwyler \& Houde 1970, Houde \& Lovdal 1984, Breitburg 1991). Predators of naked goby and bay anchovy larvae include the medusa Chrysaora quinquecirrha, the ctenophore Mnemiopsis leidyi, and juvenile and adult fishes (Markle \& Grant 1970, Monteleone \& Duguay 1988, Houde \& Zastrow 1991, Cowan \& Houde 1993, Purcell et al. 1994). Highest densities of C. quinquecirrha, M. leidyi, and fish larvae all occur during summer in Chesapeake Bay, when bottom oxygen concentrations are low (Cowan \& Houde 1993).

Because predation risk is a function of predator and prey densities, prey vulnerability, and vertical and temporal overlap of predators and their prey (Williamson et al. 1989, Williamson \& Stoeckel 1990), hypoxic bottom-water may alter predation risk to fish larvae and feeding by larvae on zooplankton through its effect on densities (Howell \& Simpson 1994), vulnerability to predators (Breitburg et al. 1994, 1997) and vertical distributions (Coutant 1985, Roman et al. 1993). Earlier research on organisms in Chesapeake Bay examined distributions relative to hypoxia and hypothesized that densities and distributions reflect effects of low DO. For example, zooplankton, which usually occur in high densities near-bottom during normoxic conditions, were rare in hypoxic bottom-water (Roman et al. 1993). Bay anchovy eggs and larvae were uncommon in hypoxic subpycnocline water of mainstem Chesapeake Bay (MacGregor \& Houde 1996). Similarly, demersal and pelagic adult fishes were rare in oxygendepleted bottom-waters (Coutant 1985, Pihl et al. 1991).
Based upon laboratory experiments, larvae of the naked goby and bay anchovy are expected to move vertically to avoid bottom-layer oxygen concentrations $<2 \mathrm{mg} \mathrm{l}^{-1}$ (Breitburg 1994). If hypoxia ( $\leq 2 \mathrm{mg} \mathrm{DO} \mathrm{l}^{-1}$ ) is avoided, vertical movements would result in increased relative densities in upper layers of the water column, coinciding with decreases in subpycnocline relative densities. Concurrent movement of major predators on fish larvae and the larvae themselves could result in greater vertical overlap of larvae and predators, potentially leading to higher larval mortality. If reactions to bottom-layer hypoxia are species-specific, however, then effects of oxygen depletion on encounter rates will vary among species.

\section{MATERIALS AND METHODS}

Field collections. During the summers of 1992 and 1993, we conducted discrete-depth plankton sampling in the Patuxent River (Maryland, USA) at 2 sites that were selected based upon their history of hypoxia: (1) the mouth of St. Leonard's Creek (StL) (20 m depth), and (2) the mouth of Battle Creek (BC) (12 m depth) (Fig. 1). Sites were sampled at least once at night and once during daylight in each of 3 research cruises conducted each year (see Table 1). Prior to sampling each site, vertical profiles of temperature, salinity, and dissolved oxygen were obtained at 0.5 to $2 \mathrm{~m}$ depth intervals. The depth of the pycnocline was determined from the vertical profiles.

In 1993, water was analyzed for chlorophyll a (chl a), an indicator of phytoplankton biomass. Pumped water samples of 100 to $250 \mathrm{ml}$ were collected at surface, pycnocline, and bottom depths, and then filtered onto Whatman glass fiber filters (GFF) of $0.7 \mu \mathrm{m}$ porosity. Filters were wrapped in foil and frozen for acetoneextracted chl a analysis.

Ichthyoplankton and gelatinous zooplankton were collected with a $1 \mathrm{~m}^{2}, 212 \mu \mathrm{m}$ mesh Tucker trawl in 1.5 min tows within the surface, pycnocline, and bottom layers at each site. Pycnocline depth was determined by temperature, salinity, and oxygen profiles. A DO probe was attached to the trawl frame to deploy the net at target depths determined by DO concentration. Water volume filtered was determined for calculation of organism densities. Mean volume $( \pm 1 \mathrm{SE})$ was $57.3 \pm 1.1 \mathrm{~m}^{3}$ for 186 samples. Duplicate samples were taken, except on the second daylight collection at each station in 1993. One of the duplicate ichthyoplankton samples from each pair was preserved in $95 \%$ ethanol; the other was preserved in $5 \%$ formalin-seawater for possible gut-content analysis. In the field, gelatinous zooplankton were identified and counted. The total biovolume of each species was measured with a grad- 
uated cylinder, and average individual biovolume was determined by dividing the total biovolume by the total number of individuals.

In the laboratory, fish eggs and larvae were counted and identified as naked goby Gobiosoma bosc, bay anchovy Anchoa mitchilli, striped blenny Chasmodes bosquianus, skilletfish Gobiesox strumosus, hogchoker Trinectes maculatus, or 'other'. If a sample had $<100$ each of goby larvae, anchovy larvae, and anchovy eggs, the whole sample was examined. If densities were higher, $1 / 2$, $1 / 4$, or $1 / 8$ aliquots were counted after splitting in a Folsom plankton splitter. A minimum of 100 each of goby larvae, anchovy larvae, and anchovy eggs was counted and removed from samples when densities were sufficient. Anchovy $\leq 25 \mathrm{~mm}$ standard length (i.e. larvae) were included in the analyses. Striped blennies, skilletfish, hogchoker, and other larvae together comprised $<2 \%$ of the total; the specific results of analyses on those species are not presented here, but can be found in Keister (1996).

To differentiate effects of bottom DO on sizeclasses of naked goby larvae, standard lengths (SL) of ethanol-preserved larvae were measured to the nearest $0.01 \mathrm{~mm}$ SL with image-analysis software. Length distributions were used to determine the proportion of goby larvae in >6.5 and $<6.5 \mathrm{~mm}$ length classes. When samples contained $>100$ larvae, subsamples of 50 to 100 were randomly chosen to be measured. The efficacy of the randomization process was tested by examining five 50-larva subsamples and testing for differences in length-frequency distributions (Kolmogorov-Smirnov tests). No 2 distributions were found to differ significantly ( $p>0.05)$.

Zooplankton was sampled at discrete depths by pumping $50 \mathrm{l}$ of water at $30 \mathrm{l} \mathrm{min}^{-1}$ and filtering it on a

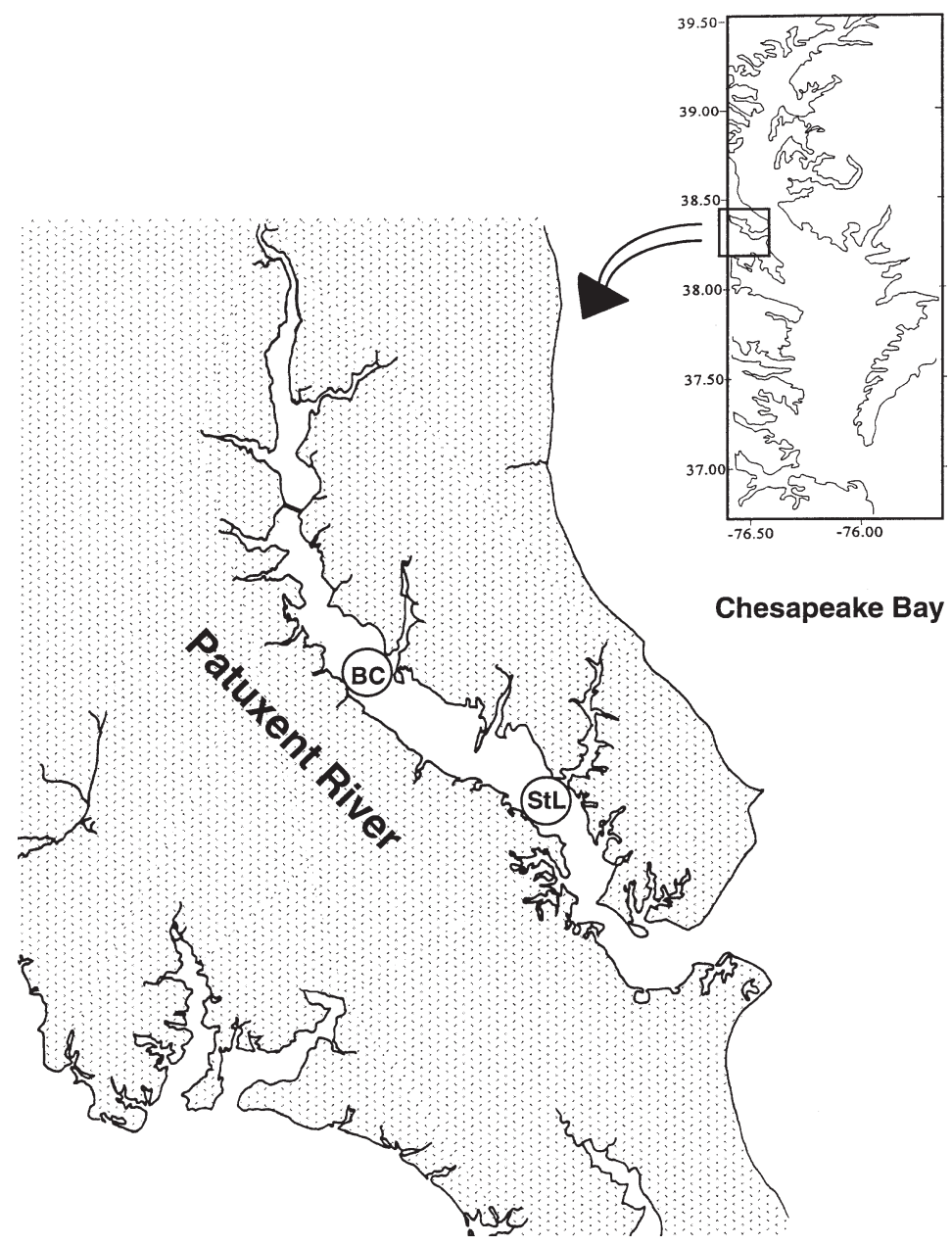

Fig. 1. Patuxent River, Chesapeake Bay sampling stations: Battle Creek (BC) and St. Leonard's Creek (StL)

$35 \mu \mathrm{m}$ mesh sieve. Samples were taken from the same depths at which the ichthyoplankton was sampled. Samples were preserved in 5\% formalin-seawater.

Table 1. Bottom-layer dissolved oxygen concentrations $\left(\mathrm{mg} \mathrm{l}^{-1}\right)$ at St. Leonard's Creek and Battle Creek sampling stations during summers of 1992 and 1993. L, H: low $\left(\leq 2 \mathrm{mg} \mathrm{l}^{-1}\right)$ and high $\left(>2 \mathrm{mg} \mathrm{l}^{-1}\right)$ relative bottom-layer dissolved oxygen concentrations.

Days 1 and 2: first and second occupations of a station during daylight. ns: no sample

\begin{tabular}{|c|c|c|c|c|c|c|}
\hline \multirow[t]{2}{*}{ Sampling station } & \multicolumn{3}{|c|}{$1992-$} & \multirow[b]{2}{*}{$\begin{array}{l}\text { Cruise } 1 \\
\text { (6-7 Jul) }\end{array}$} & \multirow{2}{*}{$\begin{array}{c}1993- \\
\text { Cruise } 2 \\
(12-13 \text { Jul })\end{array}$} & \multirow[b]{2}{*}{$\begin{array}{c}\text { Cruise } 3 \\
\text { (16-17 Jul }\end{array}$} \\
\hline & $\begin{array}{c}\text { Cruise } 1 \\
\text { (23-25 Jul) }\end{array}$ & $\begin{array}{c}\text { Cruise } 2 \\
\text { (28-30 Jul) }\end{array}$ & $\begin{array}{l}\text { Cruise } 3 \\
\text { (3-5 Aug) }\end{array}$ & & & \\
\hline \multicolumn{7}{|l|}{ St. Leonard's Creek } \\
\hline Day 1 & $4.2(\mathrm{H})$ & $5.2(\mathrm{H})$ & $3.4(\mathrm{H})$ & $2.0(\mathrm{~L})$ & $0.03(\mathrm{~L})$ & $0.04(\mathrm{~L})$ \\
\hline Day 2 & ns & ns & $\mathrm{ns}$ & $2.9(\mathrm{H})$ & 0.03 (L) & $0.03(\mathrm{~L})$ \\
\hline Night & $3.5(\mathrm{H})$ & $4.6(\mathrm{H})$ & $5.7(\mathrm{H})$ & $2.1(\mathrm{H})$ & $0.00(\mathrm{~L})$ & $0.04(\mathrm{~L})$ \\
\hline \multicolumn{7}{|l|}{ Battle Creek } \\
\hline Day 1 & $0.7(\mathrm{~L})$ & $4.0(\mathrm{H})$ & $3.8(\mathrm{H})$ & $1.3(\mathrm{~L})$ & $0.2(\mathrm{~L})$ & $0.06(\mathrm{~L})$ \\
\hline Day 2 & ns & ns & ns & $1.3(\mathrm{~L})$ & $0.2(\mathrm{~L})$ & $0.02(\mathrm{~L})$ \\
\hline Night & $0.4(\mathrm{~L})$ & $4.9(\mathrm{H})$ & $3.8(\mathrm{H})$ & $3.0(\mathrm{H})$ & $0.1(\mathrm{~L})$ & $0.07(\mathrm{~L})$ \\
\hline
\end{tabular}


Zooplankton were identified and counted in the laboratory. Samples were concentrated so that the density was judged to be about 100 organisms ml-1. Three $1 \mathrm{ml}$ subsamples were counted, the mean was calculated, and the density of organisms sampled was determined. Copepods were not identified to species, but were classified as adults and juveniles (copepodites) or nauplii. All non-gelatinous zooplankton, other than copepods, were grouped as 'other' zooplankton for statistical analyses.

Densities $(D)$ of organisms were calculated. Fish larvae are reported as number $\mathrm{m}^{-3}$, gelatinous predators are reported as number $\mathrm{m}^{-3}$ and as biovolume $\left(\mathrm{ml} \mathrm{m}^{-3}\right)$, and zooplankton are reported as number $\mathrm{l}^{-1}$. Abundance at a site was calculated as $A=\sum\left(d_{i} \times D_{i}\right)$, where $A=$ abundance and $d=$ thickness of the water layer sampled (m), summed for $i$-surface, pycnocline, and bottom tows. The mean densities from duplicate tows, when made, were used for analyses.

Statistical methods. For analyses, fish larvae were grouped as all larvae, goby larvae, and anchovy larvae. Goby larvae were also classified as $<6.5$ and $>6.5 \mathrm{~mm}$ larvae. Analyses (as described in the following subsection) were performed separately on gelatinous predator numbers and biovolumes. Zooplankton grouped as copepodites, copepod nauplii, and other zooplankton were analyzed. Densities of bay anchovy eggs were analyzed, but other fish eggs, which were not identified, were not analyzed.

ANOVAs: densities and distributions. The design for collecting these data dictated the use of multivariate repeated-measures analysis of variance for data analysis (Milliken \& Johnson 1984). The water column at a point in time is the primary experimental unit of the design, and observations of organism densities in surface, pycnocline, and bottom-layers form a vector of repeated measures on that experimental unit. Because of tidal excursion, the water column at a fixed location differed between day and night, and thus DN (day vs night) is a between-units factor. Bottom-layer DO was classified as high $\left(>2.0 \mathrm{mg} \mathrm{l}^{-1}\right)$ or low $\left(\leq 2.0 \mathrm{mg} \mathrm{l}^{-1}\right)$; this relative classification is also a between-units factor. Station and cruise are between-unit factors. In summary, station, cruise, DO and DN form a factorial design of the between-units factors while depth forms a 1-way design for the within-unit factors.

An initial examination of relationships in this study between densities of fish larvae and DO suggested the use of $2.0 \mathrm{mg} \mathrm{l}^{-1}$ as the oxygen concentration below which abundances or distributions of fish larvae may be affected. The decision to use a $2.0 \mathrm{mg} \mathrm{l}^{-1}$ criterion was supported by physiological data and evidence of its potential importance to estuarine fishes (Coutant 1985, Pihl et al. 1991, 1992, Breitburg et al. 1994, Howell \& Simpson 1994).
The ANOVA model was simplified to eliminate statistical interactions that have no ecological interpretation and to allow examination of important interactions. Most of the possible interactions between factors were dropped to retain sufficient degrees of freedom in the error term and to focus on interactions of biological interest (remaining interactions are shown in Table 2). The simplified model tested main effects of depth, cruise, station, DN, and relative bottom-layer DO (relDO; i.e. $\leq 2 \mathrm{mg} \mathrm{l}^{-1} \mathrm{vs}>2 \mathrm{mg} \mathrm{l}^{-1}$ ). A significant main effect of bottom-layer DO concentration in repeated-measures ANOVAs indicates an effect of DO on density averaged across the 3 layers (surface, pycnocline, and bottom densities not weighted for thickness of the layers). This effect is referred to as an effect on whole water-column density throughout this paper. MANOVAs were used in conjunction with the repeated-measures ANOVA model to test for significant differences in densities among depths and depth interactions (Crowder \& Hand 1990). A significant depth $\times$ DO interaction indicates an effect of bottomlayer DO on vertical distribution. Pillai's trace statistic was calculated to determine significance in MANOVAs (Norusis 1993). Densities were $\log _{10}(y+1)$ transformed to meet the repeated-measures ANOVA assumptions of normality and sphericity of components (Crowder \& Hand 1990, Norusis 1993). Although statistical analysis was applied to transformed densities, untransformed means $( \pm 1 \mathrm{SE}$ ) are reported in text and tables. SAS software (SAS Institute Inc., Cary, NC) was used for all statistical analyses.

To simplify the model, year and cruises-within-ayear were combined into the single variable called 'cruise' for ANOVAs. Because a mix of high and low bottom-layer DO was seen in only 2 of the 6 cruises (Cruises 92-1 and 93-1: Table 1), relative bottom-layer DO was highly confounded with cruise. Consequently, the cruise and relDO factors could not be completely segregated in the ANOVAs using Type III sums of squares typically recommended for calculating $F$ statistics (Cody \& Smith 1991). To deal with this problem, order-dependent Type I sums of squares (SAS Institute Inc., Cary, NC) were used to examine the effect of the order of independent variables in the ANOVA model statement (E. Perry, statistical consultant, Perry Inc., Huntingtown, MD) by running the ANOVA twice, once with independent variables ordered in the model statement as cruise, station, DN, relDO, thereby giving priority to cruise, and once with the order as station, $\mathrm{DN}$, relDO, cruise, giving priority to DO. Through the use of these 2 models, the proportion of the variance in the response that is uniquely attributable to DO, the variance uniquely attributable to cruise, and the variance that might be attributed to either were evaluated. The contrasts of the repeated-measures 
analysis, density in surface minus density in bottom $\left(D_{\text {top }}-D_{\text {bot }}\right)$ and density in pycnocline minus density in bottom $\left(D_{\text {pyc }}-D_{\text {bot }}\right)$, were calculated for ANOVAs using Type I sums of squares because the repeated option used in repeated-measures analysis in SAS is incompatible with Type I sums of squares. These analyses are referred to as depth-contrast ANOVAs throughout this paper, and significant results indicate effects on vertical distributions of organisms. The results of these analyses are only discussed where they indicated that DO effects on distributions were masked by variation among cruises in the original analyses in which Type III sums of squares had been calculated.

In addition to examining the effect of bottom-layer DO on densities and distributions of organisms using the relative bottom-layer DO $\left(\leq 2\right.$ or $\left.>2 \mathrm{mg} \mathrm{l}^{-1}\right)$, we also ran analyses with measured (continuous) values of bottom-layer DO replacing 'relDO' in otherwise identical ANOVA models. Results of analyses using continuous DO were similar to those using relative bottom-layer DO (Keister 1996). Because densities of most organisms did not exhibit a linear response to DO, scaling DO to discrete classes above and below the chosen $2 \mathrm{mg} \mathrm{l}^{-1}$ threshold modeled the data better than using DO as a continuous measure, so continuous DO results are not presented here.
ANOVAs: proportion in bottom layer. Behavioral responses to low bottom-layer DO might be masked by variation in total densities of organisms in repeated-measures ANOVAs. To examine these potential changes in vertical distributions, we therefore performed an additional analysis of depth distributions by examining proportional densities of goby larvae, anchovy larvae, gelatinous predators, and zooplankton that were in the bottom layer of the water col$\mathrm{umn}_{\text {; }}$ a shift in densities will be more pronounced when examined as proportions, thereby increasing the sensitivity of analyses. For each organism, the proportional density of animals found in the bottom layer $\left(\mathrm{P}_{\text {bot }}\right)$ was calculated by $P_{\text {bot }}=D_{\text {bot }} /\left(D_{\text {top }}+D_{\text {pyc }}\right.$ $\left.+D_{\text {bot }}\right)$, where $D_{\text {top }}=$ density in the surface-layer, $D_{\text {pyc }}=$ density in pycnocline, and $D_{\text {bot }}$ is density in the bottom-layer. Because behavioral responses were of interest, numbers of gelatinous predators were used in calculations rather than biovolumes. Proportional densities were not adjusted for differences in the thickness of the surface, pycnocline, and bottomwater layers because avoidance of an area may be reflected in lowered densities in that layer irrespective of its thickness. Factorial ANOVAs, with proportional density in the bottom-layer as the dependent variable and cruise, station, $\mathrm{DN}$, relDO, station $\times \mathrm{DN}$, station $\times$ relDO, and $\mathrm{DN} \times$ relDO as independent vari-

Table 2. Effects of different factors on whole water-column densities and vertical distributions of organisms: $p$ values of factors with $\mathrm{p}>F \leq 0.10$ as investigated by repeated-measures ANOVAs and associated MANOVAs using depth as the repeated measure; $p$ values for significant factors $(\mathrm{p} \leq 0.05)$ are in bold. Significant main effects of DO indicate effects on whole water-column densities, interactions with depth test for changes in vertical distributions. Goby: Gobiosoma bosc; Anchovy: Anchoa mitchilli; Chrysaora vol.: biovolume of C. quinquecirrha; Chrysaora no.: numbers of C. quinquecirrha; Ctenophore vol.: biovolume of ctenophore Mnemiopsis leidyi; Ctenophore no.: numbers of ctenophore $M$. leidyi. DN: day/night; relDO: relative bottom-layer $\mathrm{DO}\left(\leq 2 \mathrm{mg} \mathrm{l}^{-1},>2 \mathrm{mg} \mathrm{l}^{-1}\right)$

\begin{tabular}{|c|c|c|c|c|c|c|c|c|c|c|c|c|c|c|c|}
\hline Factor & 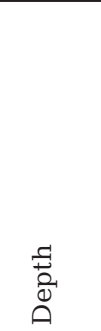 & 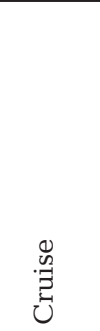 & 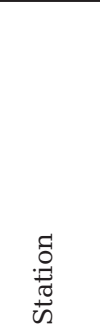 & 兄 & 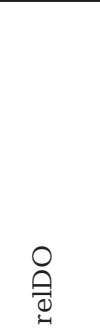 & 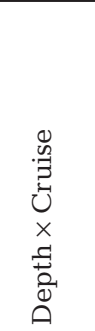 & 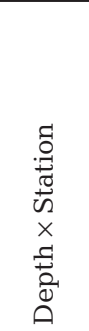 & $\begin{array}{l}Z \\
\partial \\
x \\
x \\
\overline{0} \\
\stackrel{0}{0} \\
0\end{array}$ & 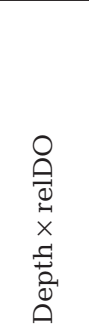 & 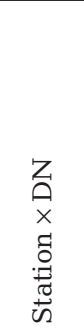 & 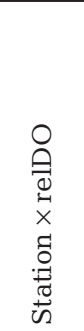 & 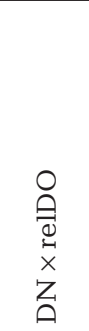 & 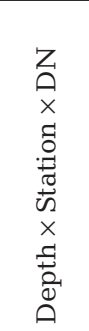 & 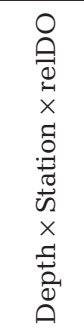 & 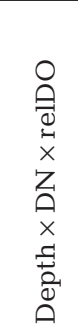 \\
\hline Chl a concentration & 0.005 & & & & & 0.054 & & 0.038 & 0.040 & & & & 0.071 & 0.070 & 0.018 \\
\hline Goby larvae & 0.0001 & 0.014 & 0.006 & 0.025 & 0.0005 & & & 0.064 & 0.031 & & & & & & \\
\hline$>6.5 \mathrm{~mm}$ goby & 0.062 & 0.017 & & 0.024 & & 0.062 & & 0.003 & & & 0.057 & & & & 0.006 \\
\hline$<6.5 \mathrm{~mm}$ goby & 0.0001 & 0.012 & 0.003 & 0.052 & 0.0002 & & & & 0.035 & & & & & & \\
\hline Anchovy larvae & 0.041 & 0.001 & & & 0.019 & & & & & & & & 0.009 & & \\
\hline Anchovy eggs & & 0.040 & 0.0002 & & & & & 0.058 & & 0.012 & & 0.095 & & 0.032 & \\
\hline Chrysaora vol. & 0.0001 & & & & & & & & & & & & & & \\
\hline Copepod nauplii & 0.0001 & 0.0001 & & & 0.030 & 0.054 & 0.041 & & 0.085 & & & & & & \\
\hline Other zooplankton & 0.0001 & & & & & & & & 0.006 & & & & & & \\
\hline
\end{tabular}


ables, were applied. To prevent samples with small numbers of animals from strongly influencing proportional density data, only samples with $>10$ animals in the water column were included. Proportion data were arcsine-transformed to meet the homogeneous variance and normality assumptions of ANOVA. ANOVAs for each organism were run twice, once with the term relDO ( $\leq 2$ or $\left.>2 \mathrm{mg} \mathrm{l}^{-1}\right)$, and once with DO as a continuous variable, to explore whether response to bottom-layer DO was a linear or threshold response.

\section{RESULTS}

\section{Hydrography}

Dissolved oxygen concentration varied among cruises and stations (Table 1). Differences among cruises were primarily due to differences between years. DO varied among depths, averaging (all samples combined) $7.4 \pm 0.3 \mathrm{mg} \mathrm{l}^{-1}$ in the surface layer, $4.5 \pm$ $0.2 \mathrm{mg} \mathrm{l}^{-1}$ in the pycnocline, and $1.9 \pm 0.4 \mathrm{mg} \mathrm{l}^{-1}$ near the bottom. Bottom DO concentrations ranged from 0 to $5.7 \mathrm{mg} \mathrm{l}^{-1}$. Temperature and salinity also varied among depths. Mean temperatures were $28.1 \pm 0.2^{\circ} \mathrm{C}$, $27.4 \pm 0.2^{\circ} \mathrm{C}$, and $25.7 \pm 0.2^{\circ} \mathrm{C}$ in the surface, pycnocline, and bottom layers, respectively. Overall mean salinity was $12.6 \pm 0.2 \mathrm{psu}$. Salinity was typically $1.5 \mathrm{psu}$ higher near the bottom than near the surface. Salini- ties were markedly higher during the 1992 cruises than during the 1993 cruises $(14.4 \pm 0.2$ psu vs $11.5 \pm$ $0.4 \mathrm{psu})$. Mean depth to mid-pycnocline was $5.3 \pm$ $0.27 \mathrm{~m}$ and ranged from 1.5 to $10.0 \mathrm{~m}$. When bottomlayer DO was low, the oxycline was often very sharp, with oxygen concentrations dropping more than $1 \mathrm{mg}$ $\mathrm{l}^{-1}$ with each meter of depth. An oxycline was difficult to detect or was absent when bottom-layer DO concentrations were $>4 \mathrm{mg} \mathrm{l}^{-1}$ and when salinity and temperature varied little from surface to bottom. Low oxygen in the bottom water was associated with a strongly stratified water column.

\section{Chlorophyll a}

The mean whole water-column concentration of chl a did not differ significantly between low and high bottom-layer DO. However, diel depth distribution of chl a concentration was significantly affected by the presence of low bottom-layer DO values (Fig. 2) (depth $\times$ $\mathrm{DN} \times$ relDO interaction in Table 2 ). When bottom-layer DO was $>2 \mathrm{mg} \mathrm{l}^{-1}$, the highest concentrations of chl a occurred in the surface and pycnocline layers during the day, but were in the pycnocline and bottom at night. When bottom-layer DO was $\leq 2 \mathrm{mg} \mathrm{l}^{-1}$, and density stratification of the water column was strong, the highest concentrations of chl a were in the surface layers during both day and night, with very low concentrations in the bottom layer.

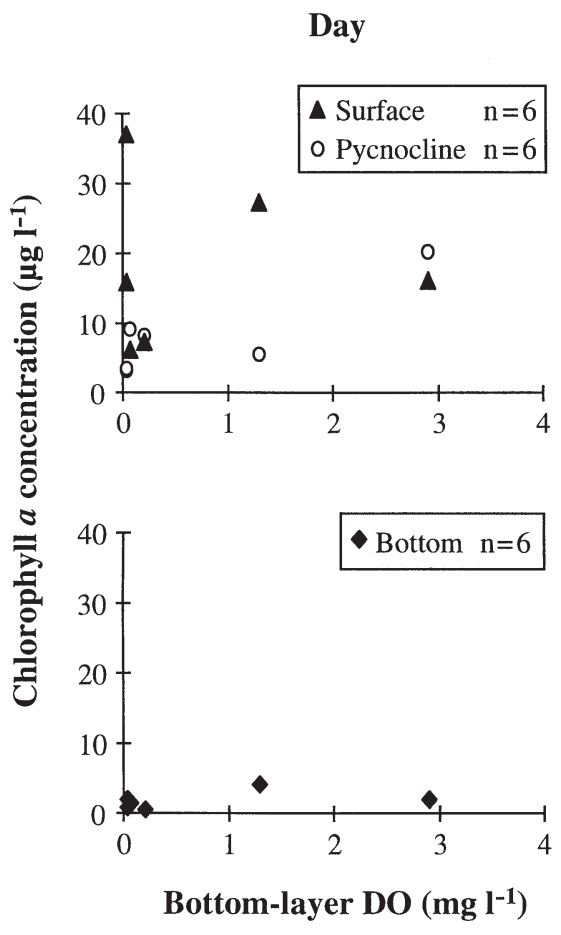

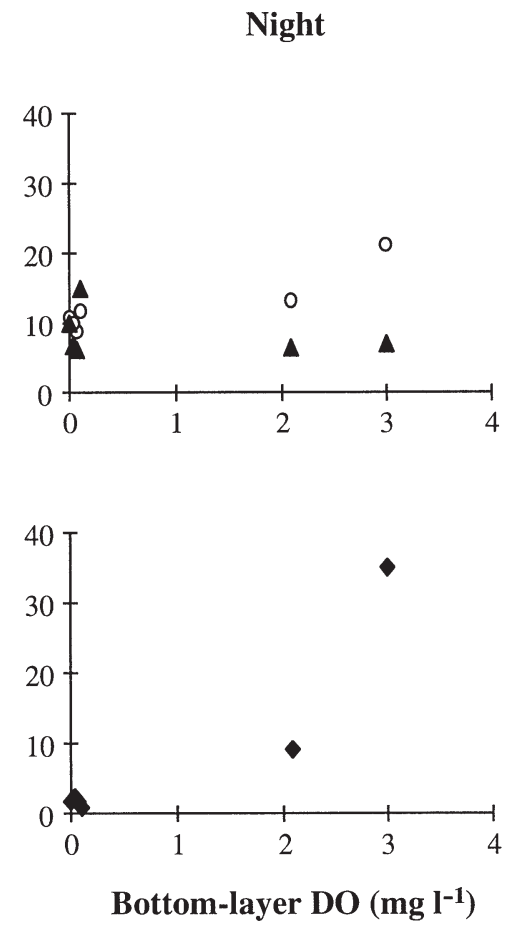

Ichthyoplankton

Bottom-layer dissolved oxygen strongly affected whole water-column densities and depth distributions of fish larvae (Figs. $3 \& 4$, Tables 2 to 4 ). When bottom-layer DO was $\leq 2 \mathrm{mg} \mathrm{l}^{-1}$, mean density of fish larvae was less than one-third that observed when bottom-layer DO was >2 $\mathrm{mg} \mathrm{l}^{-1}$ (Table 5). Although the statistical analyses examined differences in densities at DO concentrations $>$ and $\leq 2 \mathrm{mg} \mathrm{l}^{-1}$, densities of anchovy (Anchoa mitchilli) larvae tended to decrease below $\sim 3 \mathrm{mg} \mathrm{l}^{-1}$. In Cruises 92-1 and $93-1$, the only cruises in which both high and low bottom-layer DO

Fig. 2. Relationship of bottom-layer DO and diel depth distribution of chl a concentration 
occurred (Table 1), both anchovy and goby (Gobiosoma bosc) larvae had lower mean densities in samples taken when bottom-layer DO was $\leq 2 \mathrm{mg} \mathrm{l}^{-1}$ than when it was $>2 \mathrm{mg} \mathrm{l}^{-1}$, indicating that the general decline in abundances when bottom-layer DO was low was not an artifact resulting from variability among cruises.

The differences in vertical distributions with respect to bottom-layer DO were primarily due to an absence or near-absence of larvae in the bottom layer when bottom-layer DO was $\leq 2 \mathrm{mg} \mathrm{l}^{-1}$ (Fig. 4). Goby and anchovy larvae were abundant near the bottom when bottom-layer DO was $>2$ and $>3 \mathrm{mg} \mathrm{l}^{-1}$, respectively. When bottom-layer DO was low, goby larvae were most abundant in the pycnocline, while anchovy larvae were present in the pycnocline and surface samples in approximately equal densities.

Bottom-layer DO significantly affected diel differences in distributions of $>6.5 \mathrm{~mm}$ goby larvae (Fig. 5) (depth $\times$ DN $\times$ relDO interaction in Table 2$)$. When bottom-layer DO was $>2 \mathrm{mg} \mathrm{l}^{-1}$, highest densities of large goby larvae shifted from the bottom layer during the day to the pycnocline and surface at night. However, when bottom-layer DO was $\leq 2 \mathrm{mg} \mathrm{l}^{-1}$, large goby larvae were in highest densities in the pycnocline during
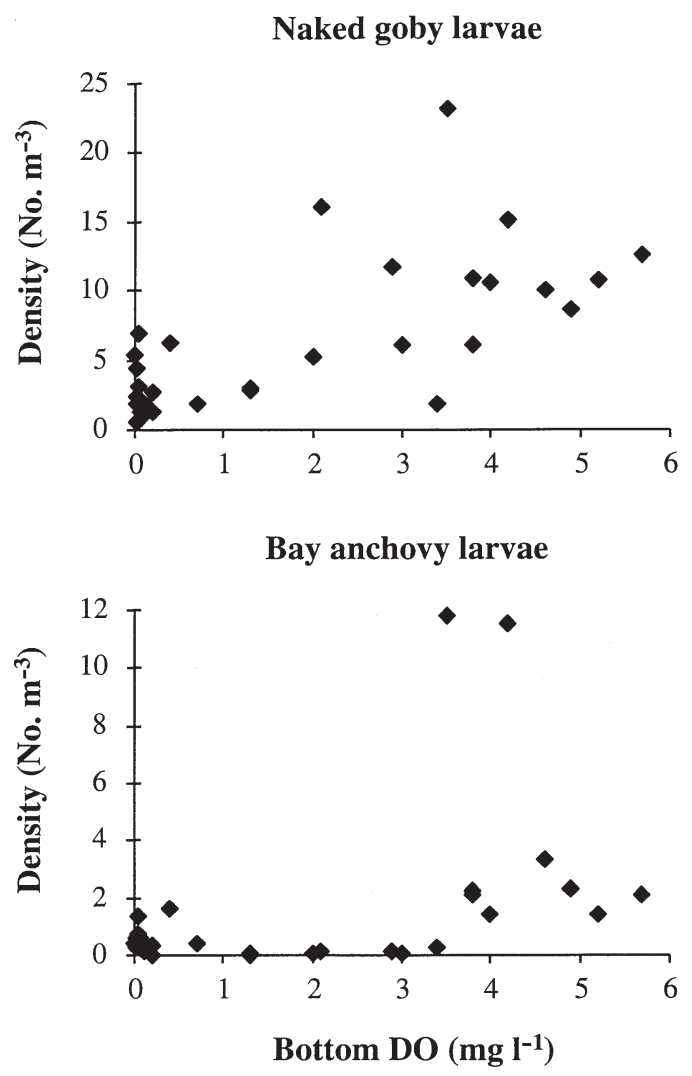

Fig. 3. Gobiosoma bosc and Anchoa mitchilli. Mean watercolumn densities of naked goby and bay anchovy larvae in relation to bottom-layer DO concentration the day and near the surface at night. No significant diel differences in depth distribution of anchovy larvae or $<6.5 \mathrm{~mm}$ goby larvae were noted with respect to relative bottom-water DO.

The proportions of goby and anchovy larvae in the bottom layer differed with respect to bottom-layer DO (Fig. 6) (factorial ANOVA, goby $F=9.91 \mathrm{p}=0.006$; anchovy $F=56.91 \mathrm{p}=0.0001$ [Type I sums of squares]). For goby larvae, the proportion found in the bottom layer did not differ significantly with respect to any other variable investigated. Both goby and anchovy larvae were present in the bottom layer in much lower proportions when bottom-layer DO was $\leq 2 \mathrm{mg} \mathrm{l}^{-1}$ than when bottom-layer DO was $>2 \mathrm{mg} \mathrm{l}^{-1}$. The gradual decline in bay anchovy proportional densities in the bottom layer with respect to declining DO did not indicate strong threshold behavioral response (Fig. 6).

\section{Bay anchovy eggs}

Mean whole water-column density of bay anchovy eggs was not significantly affected by DO. Overall, there were more bay anchovy eggs at Stn StL than at Stn BC $\left(66.2 \pm 19.0\right.$ vs $12.0 \pm 3.7$ eggs $\left.\mathrm{m}^{-3}\right)$. At both stations, the depth distribution of bay anchovy eggs differed between times of high and low bottom-layer DO, although different distributions were seen at each station (Table 2, Fig. 7), producing a significant depth $\times$ station $\times$ relDO interaction (MANOVA, $p=0.03$ ). At StL, bay anchovy egg densities were highest near the bottom when bottom-layer DO was $>2 \mathrm{mg} \mathrm{l}^{-1}$, but highest in the surface and lowest near the bottom when bottom-layer DO was $\leq 2 \mathrm{mg} \mathrm{l}^{-1}$. At Stn BC, where egg densities were low, most eggs were found near the surface or in the pycnocline, and few were near the bottom, regardless of bottom-layer DO. Although the whole water-column density of eggs varied significantly among cruises, cruise was not a significant factor affecting depth distributions (Table 2).

\section{Gelatinous predators}

\section{Scyphomedusan Chrysaora quinquecirrha}

The vertical distribution of Chrysaora quinquecirrha was significantly affected by bottom-layer DO (Tables $2 \& 4$ ). When bottom-layer DO was $>2 \mathrm{mg} \mathrm{l}^{-1}$, C. quinquecirrha was in highest densities in the pycnocline and bottom layers, whereas when bottom-layer DO was $\leq 2 \mathrm{mg} \mathrm{l}^{-1}, C$. quinquecirrha was in lowest densities near the bottom (Fig. 8). Biovolume densities were significantly higher near surface (Student's $t=2.61$, $\mathrm{p}=0.014)$ and in the pycnocline $(t=2.08, \mathrm{p}=0.047)$ 
Naked goby larvae

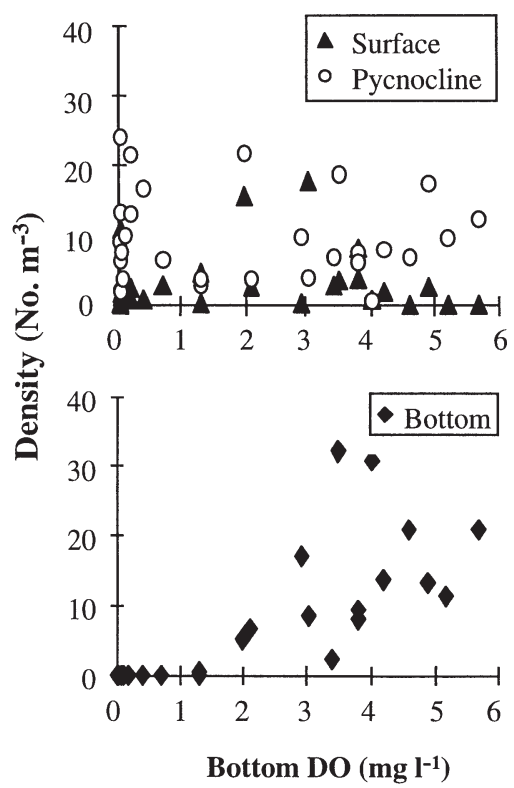

Bay anchovy larvae

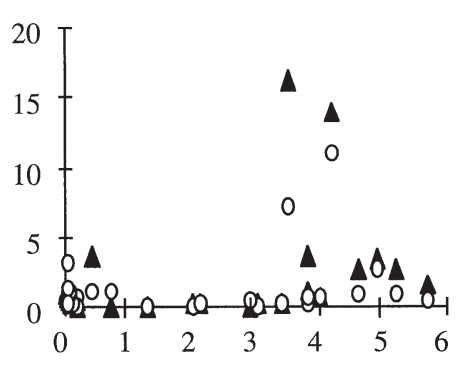

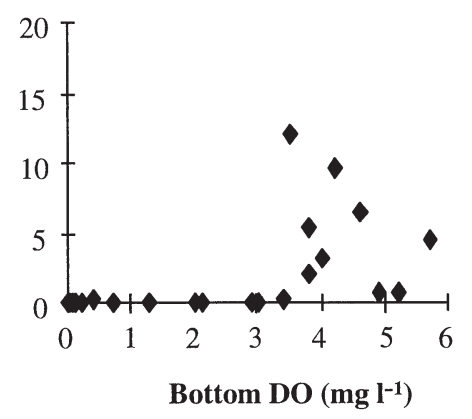

when bottom-layer DO was $\leq 2 \mathrm{mg} \mathrm{l}^{-1}$ than when bottom-layer DO was $>2 \mathrm{mg} \mathrm{l}^{-1}$, indicating movement towards the surface layer under low DO conditions. Mean density and biovolume of $C$. quinquecirrha throughout the water column did not differ between conditions of high and low bottom-layer DO.
Fig. 4. Gobiosoma bosc and Anchoa mitchilli. Densities of naked goby and bay anchovy larvae in 3 depth zones with respect to bottomlayer DO concentration

The proportional density of Chrysaora quinquecirrha (numbers $\mathrm{m}^{-3}$ ) in the bottom layer also differed with respect to bottom-layer DO (Fig. 8; Type I sums of squares). Mean proportional density in the bottom layer decreased from $0.37 \pm$ 0.06 when bottom-layer DO was $>2 \mathrm{mg}$ $\mathrm{l}^{-1}$ to $0.05 \pm 0.02$ when bottom-layer DO was $\leq 2 \mathrm{mg} \mathrm{l}^{-1}$. Observed proportional densities of $C$. quinquecirrha in the bottom layer peaked at 3 to $4 \mathrm{mg} \mathrm{DO}^{-1}$ and decreased at DO levels $>4 \mathrm{mg} \mathrm{l}^{-1}$ (Fig. 8). This shift of medusae out of the bottom layer at high DO levels probably was not a direct response to higher DO, since DO concentrations were even higher in the pycnocline and surface than near bottom.

\section{Ctenophore Mnemiopsis leidyi}

The ctenophore Mnemiopsis leidyi was the predominant gelatinous predator in mean abundance and bio-

Table 3. Effects of different factors on vertical distributions of organisms: $\mathrm{p}$ values of factors with $\mathrm{p}>F \leq 0.10$ as investigated by depth-contrast ANOVAs, where (A) is surface-bottom contrast using Type III sums of squares to calculate $F$ values and (B) is pycnocline-bottom contrast using Type III sums of squares to calculate $F$ values. $p$ values for significant factors $(p \leq 0.05)$ are in bold. See Table 2 for abbreviations

\begin{tabular}{|c|c|c|c|c|c|c|c|c|c|c|c|c|c|c|}
\hline \multirow[t]{2}{*}{ Factor } & \multicolumn{7}{|c|}{ (A) Surface-bottom } & \multicolumn{7}{|c|}{ (B) Pycnocline-bottom } \\
\hline & 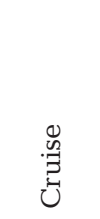 & $\begin{array}{l}\text {.0 } \\
\text { 总 } \\
\text { in }\end{array}$ & 兄 & $\stackrel{\bigcirc}{\stackrel{\ominus}{\rightleftharpoons}}$ & 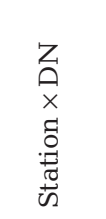 & 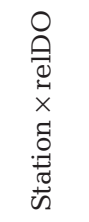 & 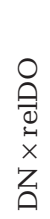 & 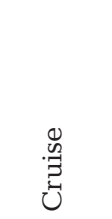 & 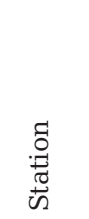 & Z & 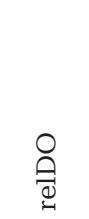 & 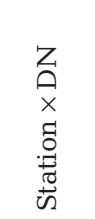 & 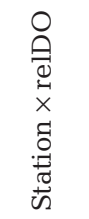 & 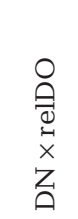 \\
\hline Chl a concentration & & 0.054 & 0.085 & 0.038 & 0.089 & 0.100 & & 0.003 & & 0.003 & 0.008 & 0.018 & 0.008 & 0.001 \\
\hline Goby larvae & & & 0.039 & 0.024 & & & & & & & 0.008 & & & \\
\hline$>6.5 \mathrm{~mm}$ goby & & & 0.0008 & & 0.067 & & & 0.033 & & 0.042 & & & & 0.001 \\
\hline$<6.5 \mathrm{~mm}$ goby & 0.094 & & & 0.044 & & & & & & & 0.009 & & & \\
\hline Anchovy larvae & & & & & 0.072 & & & & & 0.078 & & 0.002 & & \\
\hline Anchovy eggs & & & & & & 0.008 & & & & & & & & \\
\hline Chrysaora vol. & & & & & & & & & & & 0.067 & & & \\
\hline Chrysaora no. & & & & 0.036 & & & & & & & 0.036 & & & \\
\hline Ctenophore vol. & 0.0001 & 0.045 & 0.056 & 0.012 & & 0.038 & & 0.0001 & 0.100 & & 0.061 & & & \\
\hline Ctenophore no. & 0.0001 & & & 0.034 & & & & 0.0003 & & & 0.004 & & & \\
\hline Copepods & 0.009 & & 0.004 & & & & & & & & 0.036 & & & \\
\hline Copepod nauplii & 0.036 & 0.055 & & 0.060 & & & & 0.006 & 0.022 & & 0.068 & & & \\
\hline Other zooplankton & & & & 0.012 & & & & & & & 0.001 & & & \\
\hline
\end{tabular}



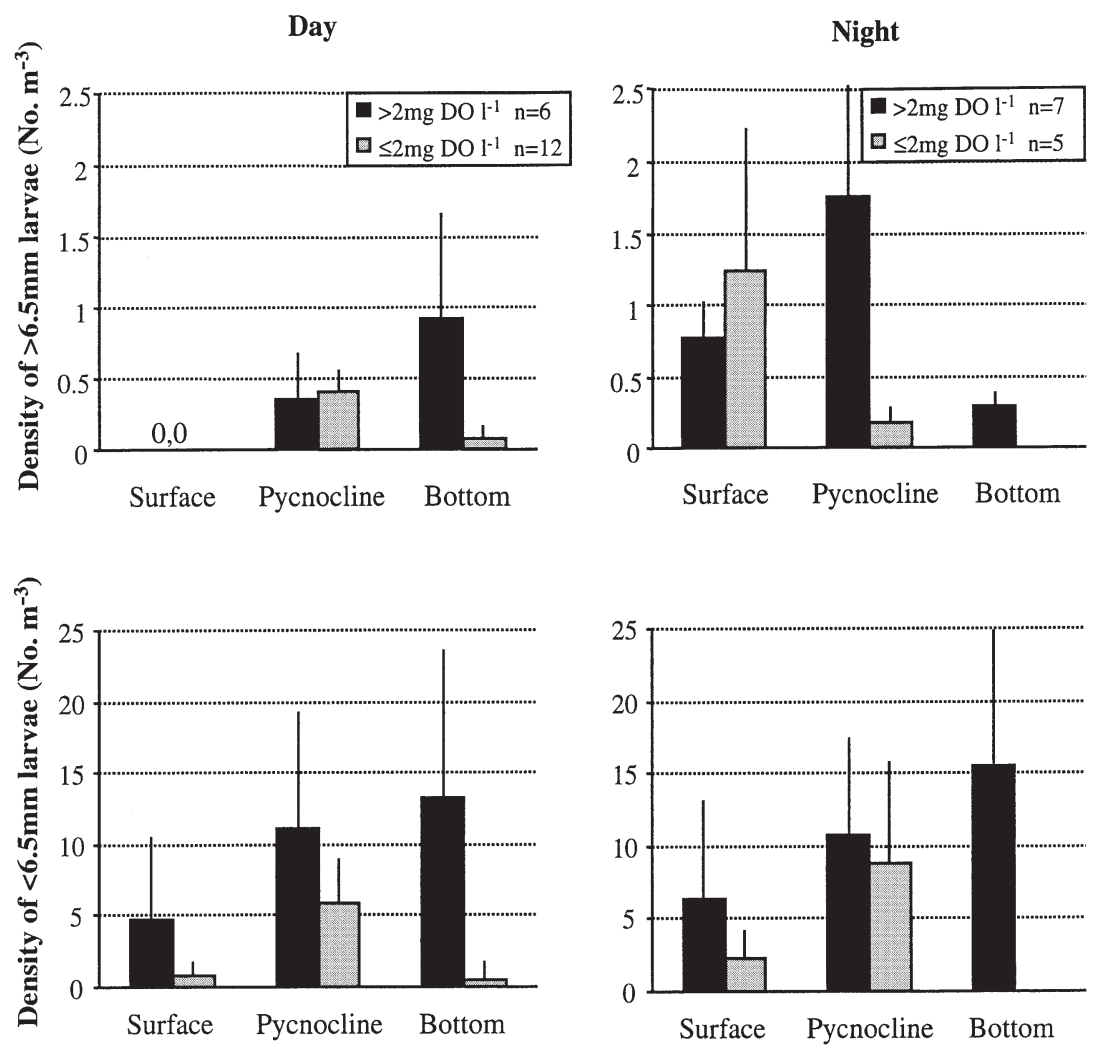

Fig. 5. Gobiosoma bosc. Diel depth distributions of $>6.5$ and $<6.5 \mathrm{~mm}$ naked goby with respect to bottom-layer DO. Sample sizes (n) are for each depth volume when averaged across all cruises (Table 5). However, biovolumes and densities were highly variable, primarily due to variability among sampling dates. Over $98 \%$ of the total biovolume and $99 \%$ of total numbers of ctenophores sampled were collected during Cruise 93-1 (data between 1 and $3 \mathrm{mg}$ DO $\mathrm{l}^{-1}$ in Fig. 9). Densities in other cruises were low.

Repeated-measures ANOVAs revealed a significant decrease in whole water-column density of ctenophores (as numbers $\mathrm{m}^{-3}$ ) when bottom-layer DO was $\leq 2 \mathrm{mg} \mathrm{l}^{-1} \mathrm{com}$ pared to when it was $>2 \mathrm{mg} \mathrm{l}^{-1}$ (Table 2). However, inspection of Figs. 9 \& 10 suggests that ctenophores may strongly avoid bottomlayer hypoxia, but only when bottom DO concentrations are $<1 \mathrm{mg} \mathrm{l}^{-1}$. Similarly, the depth distribution of ctenophores differed between high and low bottom-layer DO but, unlike other organisms surveyed, mean ctenophore densities were highest in the bottom layer under both high and low bottom-layer conditions when a

Table 4. Effects of different factors on vertical distributions of organisms: $\mathrm{p}$ values of factors with $\mathrm{p}>F \leq 0.10$ as investigated by depth-contrast ANOVAs, where (A) is surface-bottom contrast using Type I sums of squares to calculate $F$ values and (B) is pycnocline-bottom contrast using Type I sums of squares to calculate $F$ values. p values for significant factors $(p \leq 0.05)$ are in bold. See Table 2 for abbreviations

\begin{tabular}{|c|c|c|c|c|c|c|c|c|c|c|c|c|c|c|}
\hline \multirow[t]{2}{*}{ Factor } & \multicolumn{7}{|c|}{ (A) Surface-bottom } & \multicolumn{7}{|c|}{ (B) Pycnocline-bottom } \\
\hline & $\begin{array}{l}0 \\
\stackrel{0}{0} \\
\text { is }\end{array}$ & $Z_{\text {兄 }}$ & 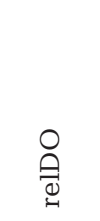 & 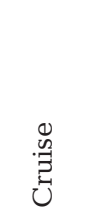 & 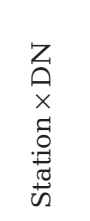 & 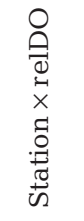 & 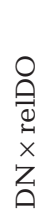 & 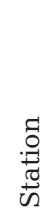 & 胎 & $\stackrel{\circlearrowright}{\underset{\sim}{ٍ}}$ & 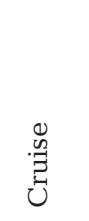 & 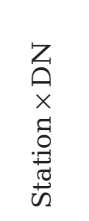 & 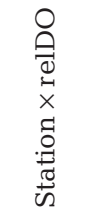 & 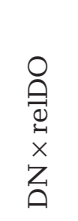 \\
\hline Chl a concentration & & 0.014 & 0.012 & & 0.095 & 0.045 & & & 0.085 & 0.004 & 0.003 & 0.040 & 0.0007 & 0.001 \\
\hline Goby larvae & & & 0.0001 & & & & & & & & & & & \\
\hline$>6.5 \mathrm{~mm}$ goby & & 0.002 & 0.054 & 0.077 & & & & & 0.021 & & & & & 0.001 \\
\hline$<6.5 \mathrm{~mm}$ goby & & & 0.0001 & 0.052 & & & & & & 0.0001 & & & & \\
\hline Anchovy larvae & & & 0.0005 & & 0.054 & & & & & 0.004 & & 0.002 & & \\
\hline Anchovy eggs & & & 0.042 & & & 0.012 & & & & 0.016 & & & & \\
\hline Chrysaora vol. & & & 0.0001 & & & & & & & 0.0001 & & & & \\
\hline Chrysaora no. & & & 0.0006 & & & & & & & 0.036 & & & & \\
\hline Ctenophore vol. & & 0.002 & & 0.0001 & & 0.037 & & & & 0.0001 & & & & \\
\hline Ctenophore no. & & 0.032 & & 0.0001 & & & & & & & 0.0002 & & & \\
\hline Copepodites & & & 0.0001 & 0.010 & & & & & 0.004 & & 0.009 & & & \\
\hline Copepod nauplii & & & 0.0001 & 0.043 & & & & & & 0.0001 & 0.004 & & & \\
\hline Other zooplankton & & & 0.0001 & & & & & & & 0.0001 & & & & \\
\hline
\end{tabular}




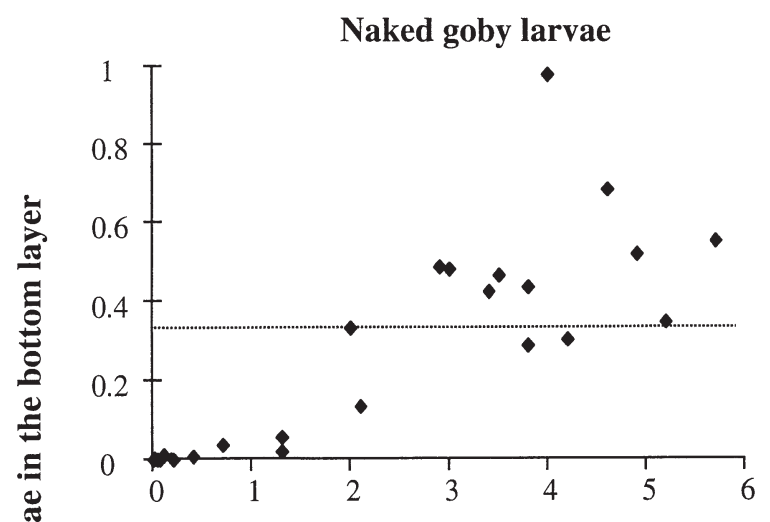

Bay anchovy larvae

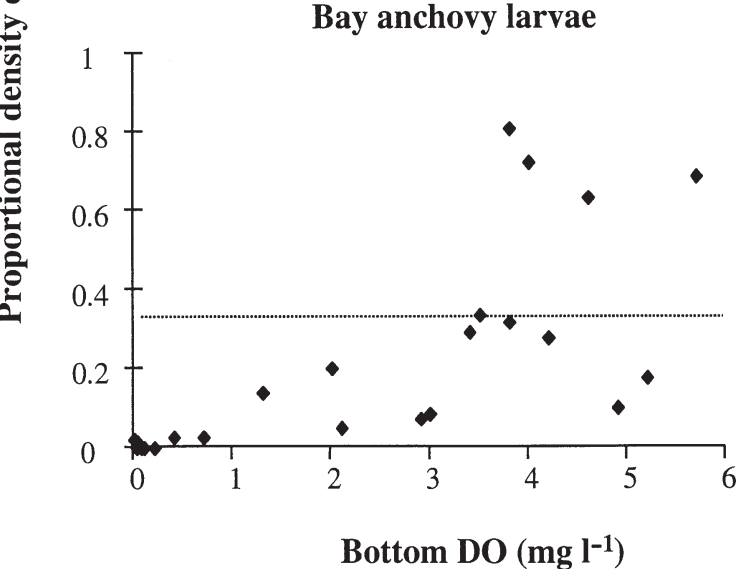

Fig. 6. Gobiosoma bosc and Anchoa mitchilli. Relationships between proportional density of naked goby larvae and bay anchovy larvae in the bottom layer of water column and bottom-layer DO; 30 observations represented by each plot, with many observations at $\sim 0 \mathrm{mg} \mathrm{DO} \mathrm{l}^{-1}$. Horizontal dotted line at 0.33 represents expected proportional density in the bottom layer if larvae were randomly distributed $\leq 2 \mathrm{mg} \mathrm{l}^{-1}$ cut-off was used to define hypoxia because of high densities collected in bottom waters of between 1 and $2 \mathrm{mg} \mathrm{l}^{-1} \mathrm{DO}$.

The proportional density of ctenophores in the bottom-layer varied significantly among cruises and with relative bottom-layer DO $(F=5.82 \mathrm{p}=0.047$; Type I sums of squares) (Fig. 10). Proportionally fewer ctenophores were in the bottom layer when bottom-layer DO was very low; the proportional density near the bottom was nearly zero at $<0.5 \mathrm{mg} \mathrm{l}^{-1}$, but above 0.7 at $1.3 \mathrm{mg} \mathrm{l}^{-1}$ (Fig. 10). No factor other than DO and cruise significantly influenced the proportion of ctenophores in the bottom layer.

\section{Zooplankton}

Bottom-layer dissolved oxygen affected both whole water-column densities and depth distributions of zooplankton. All zooplankton were rare in the bottom layer when bottom-layer DO was $\leq 2 \mathrm{mg} \mathrm{l}^{-1}$, but abundant in the bottom layer when bottom-layer DO was $>2 \mathrm{mg} \mathrm{l}^{-1}$ (Fig. 11) (Tables 2 to 5). The mean whole water-column density of copepod nauplii was significantly lower when bottom-layer DO concentrations were $\leq 2 \mathrm{mg} \mathrm{l}^{-1}$ than when bottom-layer DO concentrations were $>2 \mathrm{mg} \mathrm{l}^{-1}$ (Tables $2 \& 5$ ). Within Cruises 92-1 and 93-1, the only cruises with a mix of high and low bottom DO, mean water-column densities of copepod nauplii decreased with increasing bottom hypoxia, indicating that differences were not due to differences between years. Copepodites and 'other' zooplankton, composed primarily of tintinnids and rotifers, did not decrease significantly in mean density with low DO (Table 5), but during episodes of bottom-layer hypoxia all tended to be found in lower numbers. Fig. 11 suggests that zooplankton actually might be less abundant in bottom waters should the bottom DO concentration be $<3 \mathrm{mg} \mathrm{l}^{-1}$ rather than the $\leq 2 \mathrm{mg} \mathrm{l}^{-1}$ cut-off level selected for this study.

Proportions of all types of zooplankton in the bottom layer were greatly affected by either bottom-layer DO or relative bottom-layer DO. All zooplankton were proportionally less common in the bottom layer when bottom-layer DO was $\leq 2 \mathrm{mg} \mathrm{l}^{-1}$ (Fig. 12).

Copepodites differed significantly in day-night depth distributions (depth $\times$ DN in Table 2 ). Overall, the copepodites were

Fig. 7. Anchoa mitchilli. Mean densities of bay anchovy eggs at 3 depths in relation to bottom-layer DO at St. Leonard's Creek and Battle Creek. Sample sizes (n) are for each depth 
most abundant in the pycnocline, a pattern that was accentuated during the day when densities near the surface decreased. During both day and night, copepod nauplii were most abundant near the surface, and 'other' zooplankton were most abundant in the pycnocline. Bottom oxygen concentration did not significantly affect the diel depth distributions of the zooplankton.
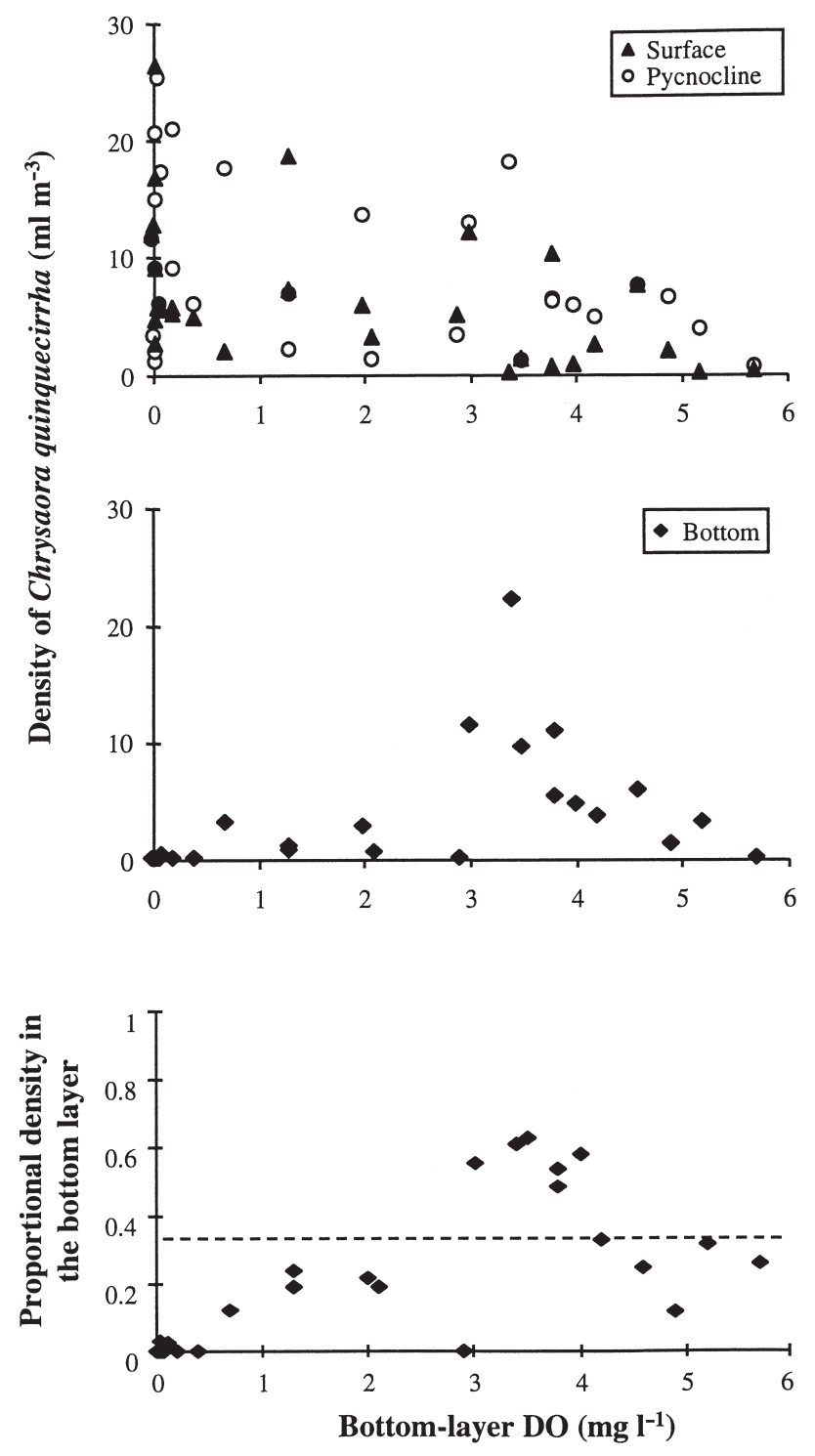

Fig. 8. Chrysaora quinquecirrha. Top and middle panels: relationship between bottom-layer DO concentration and depth for biovolume of scyphomedusan. Bottom panel: influence of bottom-layer DO on the proportional density of C. quinquecirrha in the bottom-layer of water column; 30 observations are represented, with many observations at $\sim 0 \mathrm{mg} \mathrm{DO}^{-1}$. Horizontal dashed line at 0.33 represents expected proportional density in the bottom layer if $C$. quinquecirrha were randomly distributed

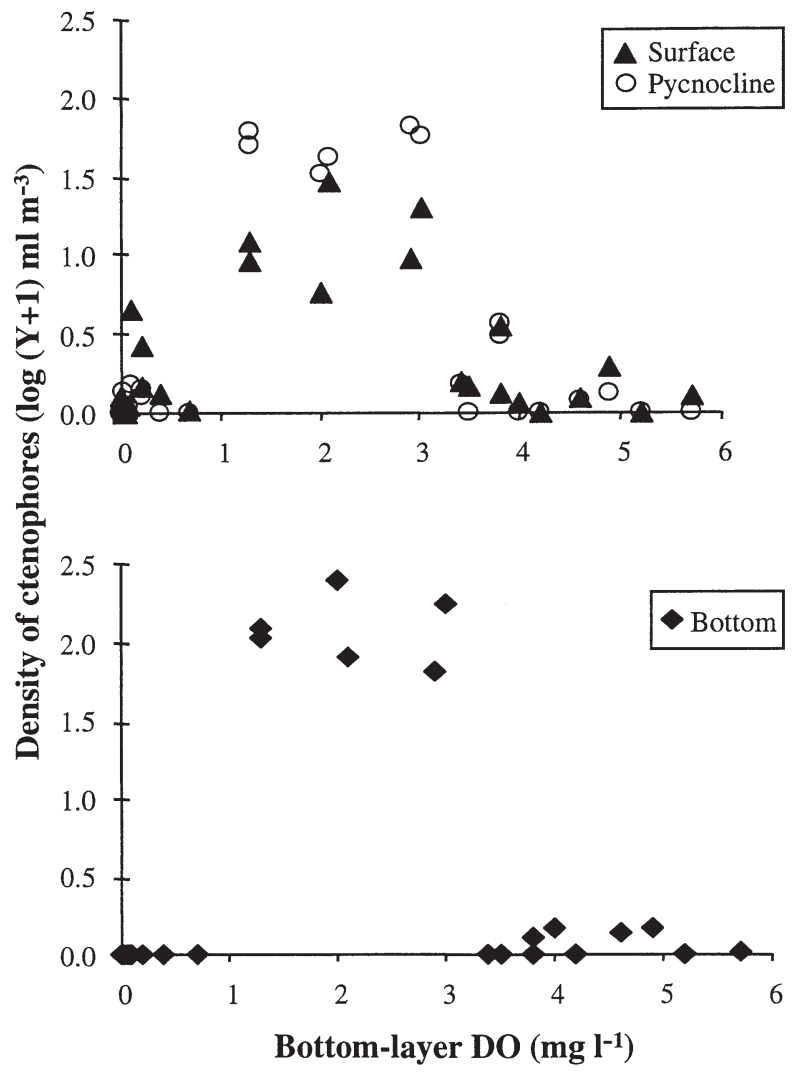

Fig. 9. Mnemiopsis leidyi. Relationship between bottom-layer DO concentration and depth for ctenophore biovolume

\section{DISCUSSION}

In Chesapeake Bay, fish larvae and their zooplankton prey were less abundant when bottom-layer DO levels were hypoxic than when bottom DO was $>2 \mathrm{mg}$ $\mathrm{l}^{-1}$. In addition, the vertical distributions of fish larvae, gelatinous predators, zooplankton prey, and chl a were influenced by bottom-layer DO levels. These results suggest that bottom-layer hypoxia, like that observed in Chesapeake Bay and many other aquatic systems including the Gulf of Mexico (Dortch et al. 1994, Rabalais et al. 1996), Long Island Sound (Howell \& Simpson 1994), and the Adriatic Sea (Barmawidjaja et al. 1995), can alter community dynamics and predator-prey relationships, and may influence recruitment rates of vulnerable organisms. Decreased whole-water column densities of organisms when bottom water is hypoxic may derive from a combination of factors. Densities of fish larvae may decrease throughout the water column because of avoidance of hypoxic areas by spawning adults, decreased hatch-rate of eggs, or direct mortality of the youngest, most weakly swimming larvae. Lower densities of copepod nauplii during hypoxic 


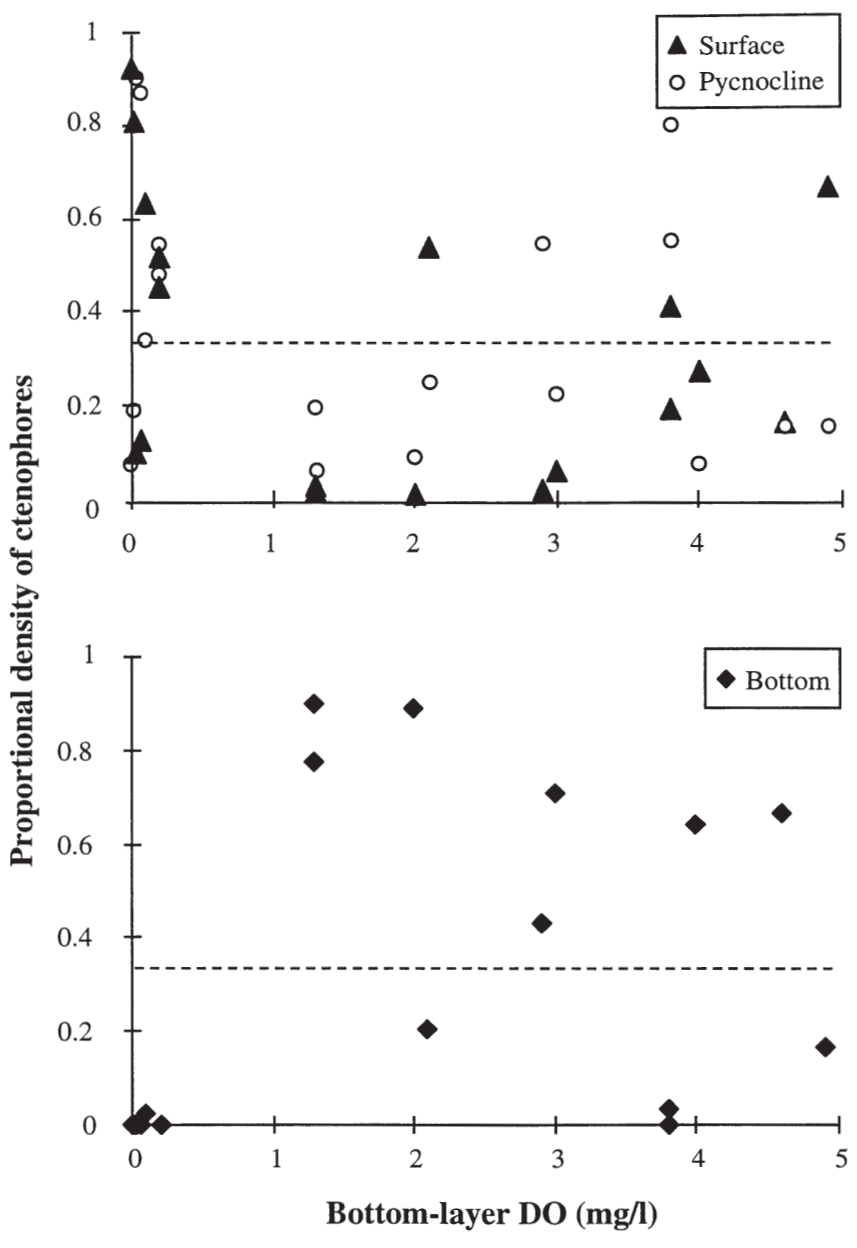

Fig. 10. Mnemiopsis leidyi. Relationship of bottom-layer DO and proportional density of ctenophores in the bottom layer of water column; 30 observations are represented, with many observations at $\sim 0 \mathrm{mg} \mathrm{DO}{ }^{-1}$. Horizontal dashed line at 0.33 represents expected proportional density in the bottom layer if ctenophores were randomly distributed

events could be a consequence of copepod mortality or of low hatch rates at $\mathrm{DO}<2 \mathrm{mg} \mathrm{l}^{-1}$ (Roman et al. 1993). In addition, low DO can increase predation mortality by increasing vulnerability or encounter rates (Breitburg et al. 1997, 1999).

Because bottom oxygen was predominantly high in 1992, but predominantly low in 1993, annual differences and effects of bottom-water DO concentrations are not easily separated. This was problematical in understanding variation in densities between years or cruises, but it is reasonable to assume that vertical distributions within a collection of matched surface, pycnocline, and bottom samples is due to behavioral responses and/or mortality differences in organisms in the 3 layers of the water column. Generally, when the effect of bottom-layer DO on overall densities was significant in ANOVAs, there was a pattern of decreased organism densities with decreased bottom oxygen concentrations in Cruises 92-1 and 93-1, the 2 cruises in which both high and low bottom-layer DO were observed. This pattern supports the idea that low oxygen was an important factor influencing the abundance of fish larvae and zooplankton. Interestingly, this observation was not true for ctenophores, which occurred in high abundances in hypoxic bottom-water during Cruise 93-1.

\section{Ichthyoplankton}

Whole water-column densities of both naked goby Gobiosoma bosc and bay anchovy Anchoa mitchilli larvae were lower when bottom-layer DO was $\leq 2 \mathrm{mg} \mathrm{l}^{-1}$ than when bottom DO was high. In addition, vertical distributions of both fish larvae and eggs were affected by bottom-layer oxygen concentrations, with diminished densities near bottom during bottom-layer hypoxia. Goby and anchovy larvae occurred predominantly in the bottom layer when bottom-layer DO was high, but most occurred in highest densities in the pycnocline and with an average proportional density of $<10 \%$ near the bottom when bottom-layer DO was $\leq 2 \mathrm{mg} \mathrm{l}^{-1}$. When bottom oxygen was low, density of bay anchovy eggs near bottom was only about half that when oxygen concentrations were $>2 \mathrm{mg} \mathrm{l}^{-1}$. In other Chesapeake Bay studies, below-pycnocline abundances of bay anchovy eggs and larvae varied regionally and temporally with bottom DO. Similar to our results, MacGregor \& Houde (1996) found that most anchovy eggs and larvae in the mainstem of mid-Chesapeake Bay (>20 m depth) were above the pycnocline when below-pycnocline DO was $<2 \mathrm{mg} \mathrm{l}^{-1}$. In contrast, Rilling \& Houde (1999) did not find significant overall differences in above- and below-pycnocline abundances of anchovy eggs and larvae in bay-wide cruises during June/July 1993 when DO conditions were variable, except that eggs were regionally less abundant below the pycnocline in the lower bay during July.

Fish larvae in the present study did not increase in density in the surface and pycnocline layers concurrent with decreased bottom-layer densities under bottom-layer hypoxia. We believe, however, that the decreased bottom-layer densities were probably largely attributable to larvae migrating out of the bottom layer into the upper layers or being advected out of the study areas rather than a consequence of direct larval mortality. This hypothesis is supported by laboratory experiments (Breitburg 1994), in which naked goby and bay anchovy larvae detected, and migrated vertically to avoid, hypoxic bottom-water. Many fishes move vertically to avoid low oxygen concentrations, even in the absence of an oxygen gradient (Magnuson \& Karlen 
Copepodites

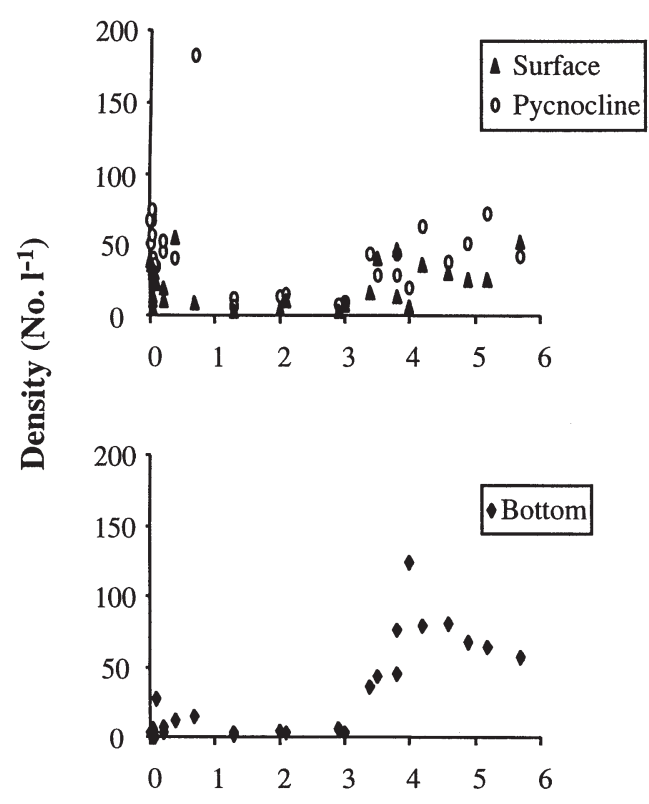

Bottom-layer DO $\left(\mathrm{mg} \mathrm{l}^{-1}\right)$
Copepod nauplii
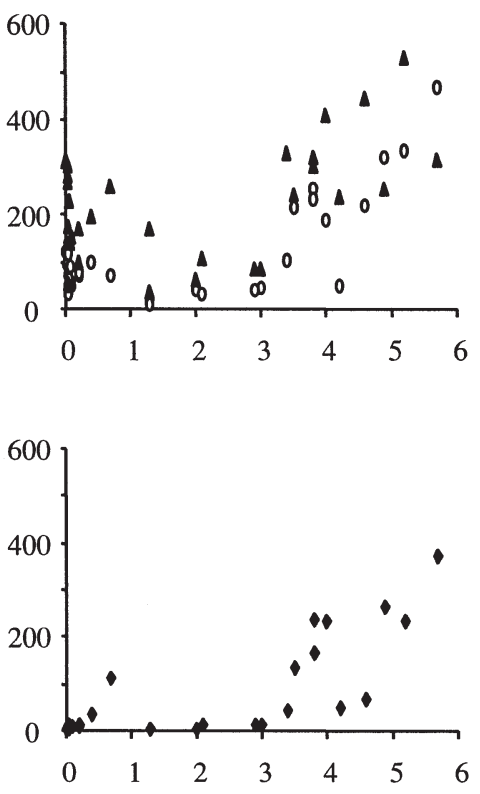

Bottom-layer DO $\left(\mathrm{mg} \mathrm{l}^{-1}\right)$
Other zooplankton
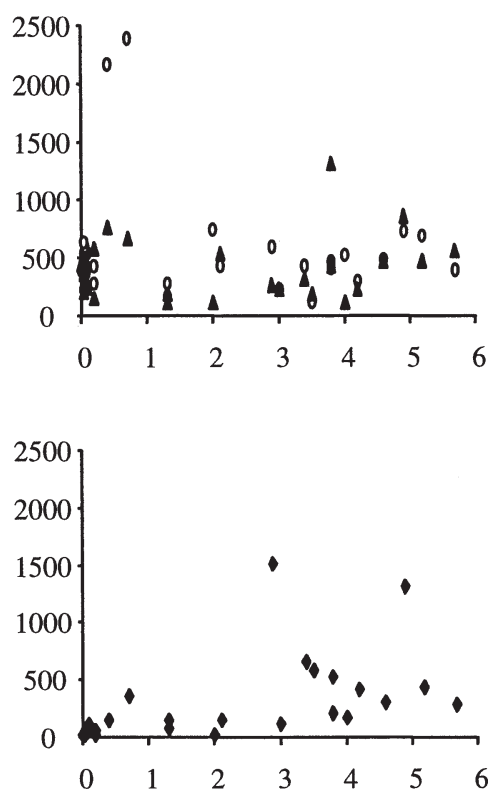

Bottom-layer DO $\left(\mathrm{mg} \mathrm{l}^{-1}\right)$

Fig. 11. Zooplankton. Relationships between bottom-layer DO concentration and depth for density of copepods and copepodites, copepod nauplii, and other zooplankton

1970, Petrosky \& Magnuson 1973, Jobling 1994). Adult and juvenile naked gobies move toward the surface or migrate to shallow inshore waters during intrusions of severely hypoxic water (Breitburg 1992). Low oxygen conditions at our sampling sites may have persisted for days to weeks, potentially altering vertical-migration behavior of larvae and leading to advection of larvae away from our sites. Additionally, possible increases in surface and pycnocline-layer densities may have been obscured by changes in predation pressure on larvae in these layers of the water column. Recent modeling to test effects of bottom-layer hypoxia on naked goby larvae predicted substantial decreases in whole watercolumn abundance attributable to Chrysaora quinque-

Table 5. Mean $\pm 1 \mathrm{SE}$ whole water-column abundances and densities of organisms at $>2 \mathrm{mg} \mathrm{l}^{-1}$ and $\leq 2$ mg l $\mathrm{l}^{-1}$ bottom-layer oxygen concentrations. Number of observations represented by each mean is given in parentheses. Mean abundance is depth-integrated, but mean density was calculated assuming equal thickness of the surface, pycnocline, and bottom layers to be consistent with calculations in the statistical analyses

\begin{tabular}{|c|c|c|c|}
\hline \multirow[t]{2}{*}{ Parameter } & \multirow{2}{*}{$\begin{array}{l}\text { Mean abundance } \\
\qquad(\mathrm{n}=30)\end{array}$} & \multicolumn{2}{|c|}{ Mean whole water-column density } \\
\hline & & $>2 \mathrm{mg} \mathrm{DO} \mathrm{l}^{-1}(\mathrm{n}=39)$ & $\leq 2 \mathrm{mg} \mathrm{DO} \mathrm{l}^{-1}(\mathrm{n}=51)$ \\
\hline All fish larvae & $115.2 \pm 22.6 \mathrm{~m}^{-2}$ & $14.3 \pm 1.8 \mathrm{~m}^{-3}$ & $3.5 \pm 0.6 \mathrm{~m}^{-3}$ \\
\hline Naked goby larvae & $91.9 \pm 16.2 \mathrm{~m}^{-2}$ & $11.0 \pm 1.4 \mathrm{~m}^{-3}$ & $3.0 \pm 0.6 \mathrm{~m}^{-3}$ \\
\hline Bay anchovy larvae & $21.6 \pm 7.9 \mathrm{~m}^{-2}$ & $3.00 \pm 0.67 \mathrm{~m}^{-3}$ & $0.5 \pm 0.1 \mathrm{~m}^{-3}$ \\
\hline Bay anchovy eggs & $491.4 \pm 133.0 \mathrm{~m}^{-2}$ & $44.5 \pm 12.9 \mathrm{~m}^{-3}$ & $35.0 \pm 14.8 \mathrm{~m}^{-3}$ \\
\hline Chrysaora quinquecirrha & $\begin{array}{r}68.1 \pm 7.4 \mathrm{ml} \mathrm{m}^{-2} \\
1.9 \pm 0.3 \mathrm{~m}^{-2}\end{array}$ & $\begin{array}{r}5.07 \pm 0.82 \mathrm{ml} \mathrm{m}^{-3} \\
0.2 \pm 0.03 \mathrm{~m}^{-3}\end{array}$ & $\begin{array}{r}6.7 \pm 1.01 \mathrm{ml} \mathrm{m}^{-3} \\
0.1 \pm 0.02 \mathrm{~m}^{-3}\end{array}$ \\
\hline Mnemiopsis leidyi & $\begin{array}{r}274.2 \pm 118.6 \mathrm{ml} \mathrm{m}^{-2} \\
101.4 \pm 42.4 \mathrm{~m}^{-2}\end{array}$ & $\begin{array}{r}13.9 \pm 5.3 \mathrm{ml} \mathrm{m}^{-3} \\
5.3 \pm 2.2 \mathrm{~m}^{-3}\end{array}$ & $\begin{array}{r}12.7 \pm 5.8 \mathrm{ml} \mathrm{m}^{-3} \\
5.0 \pm 2.4 \mathrm{~m}^{-3}\end{array}$ \\
\hline Copepodites & $3.9 \times 10^{5} \pm 4.6 \times 10^{4} \mathrm{~m}^{-2}$ & $37.3 \pm 4.4 \mathrm{l}^{-1}$ & $25.8 \pm 4.4 \mathrm{l}^{-1}$ \\
\hline Copepod nauplii & $1.7 \times 10^{6} \pm 2.5 \times 10^{5} \mathrm{~m}^{-2}$ & $204.4 \pm 22.3 \mathrm{l}^{-1}$ & $91.0 \pm 13.1 \mathrm{l}^{-1}$ \\
\hline Other zooplankton & $5.3 \times 10^{6} \pm 7.9 \times 10^{5} \mathrm{~m}^{-2}$ & $468.9 \pm 51.4 \mathrm{l}^{-1}$ & $358.6 \pm 62.3 \mathrm{l}^{-1}$ \\
\hline $\mathrm{Chl} a\left(\mu \mathrm{g} \mathrm{l}^{-1}\right)$ & $117.8 \pm 20.1(\mathrm{n}=13)$ & $14.6 \pm 3.3(\mathrm{n}=9)$ & $8.1 \pm 1.6(\mathrm{n}=27)$ \\
\hline
\end{tabular}


cirrha predation after 5 to $10 \mathrm{~d}$ of hypoxic conditions because of increased encounter rates in surface and pycnocline layers (Breitburg et al. 1999).

Decreases in whole water-column densities of larvae during hypoxic events also may be connected to avoidance of hypoxic-water areas by spawning adults, or be due to a decreased hatch-rate of anchovy and goby eggs at low DO concentrations. Bay anchovy eggs, which hatch in 18 to $24 \mathrm{~h}$, have a $12 \mathrm{~h} \mathrm{LC}_{50}$ of $2.8 \mathrm{mg}$ $\mathrm{DO}^{-1}$, and hatch rate declines significantly at DO concentrations $<3 \mathrm{mg} \mathrm{l}^{-1}$ (Chesney \& Houde 1989), indicating a potential for substantial mortality when near-bot-
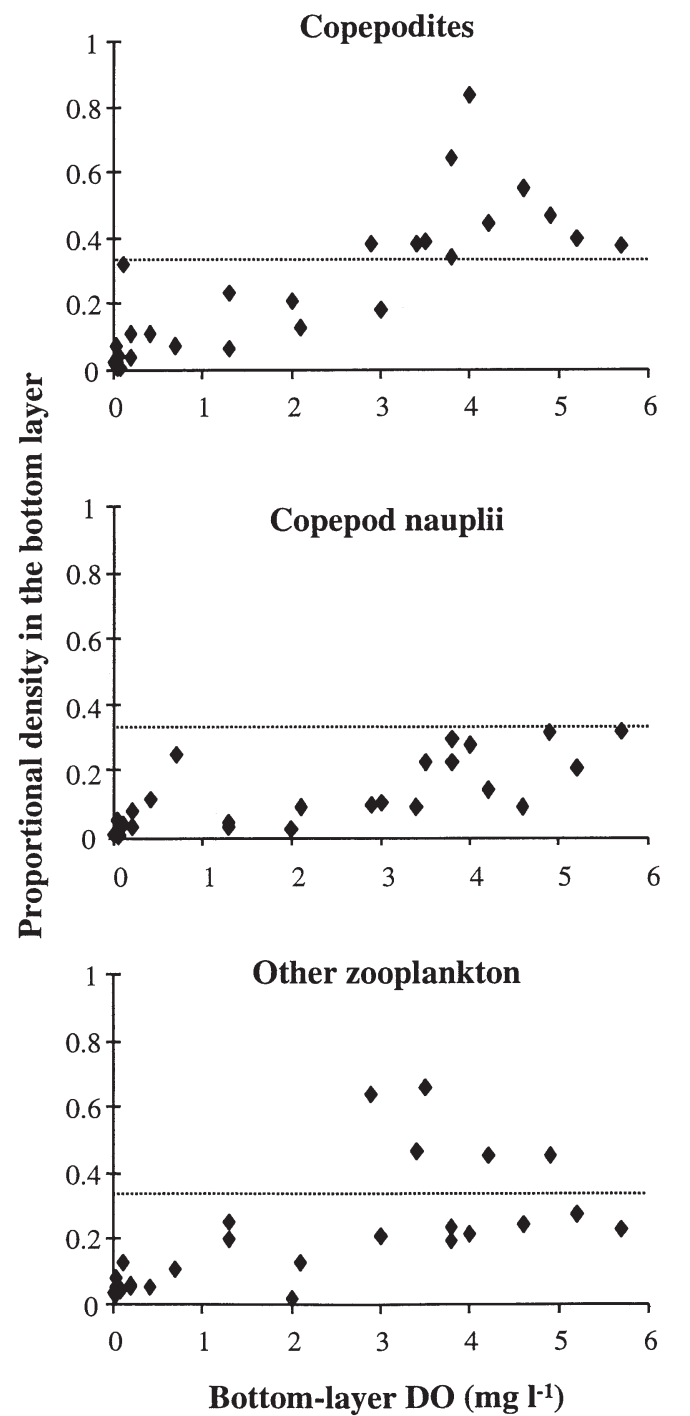

Fig. 12. Zooplankton. Relationship of bottom-layer DO and the proportional density of copepods and copepodites, copepod nauplii, and other zooplankton in the bottom layer of the water column. Horizontal dashed line at 0.33 represents expected proportional density in the bottom layer if zooplankton were randomly distributed tom oxygen concentrations are low. Naked goby eggs are benthic, and guarded by males during a 5 to $9 \mathrm{~d}$ incubation period. Laboratory and field data indicate that males will abandon nests and naked goby embryos will die during exposure to DO concentrations of 0.15 to $0.60 \mathrm{mg} \mathrm{l}^{-1}$, but that males remain with nests and embryo survival is unaffected by daily $7 \mathrm{~h}$ duration exposures to $0.74 \mathrm{mg} \mathrm{l}^{-1}$ (Breitburg 1992). Higher DO concentrations may be necessary for successful hatching of naked goby eggs if exposure to oxygen-depleted conditions last longer than several hours.

\section{Predators and prey}

Depth distributions of both medusae and ctenophores were affected by low bottom-layer DO, but in different ways. The scyphomedusan Chrysaora quinquecirrha occurred near the bottom in successively lower densities as bottom-layer DO decreased. The ctenophore Mnemiopsis leidyi was observed near the bottom in high density at 1.3 to $3.0 \mathrm{mg} \mathrm{l}^{-1}$, but at much lower densities when oxygen concentration dropped below $1.0 \mathrm{mg} \mathrm{l}^{-1}$ or when oxygen concentrations were $>3.0 \mathrm{mg} \mathrm{l}^{-1}$.

Low densities of Chrysaora quinquecirrha in moderately hypoxic bottom-water may not be a direct response to DO concentrations, since there is little evidence that they are negatively affected by moderate oxygen depletion. Both $C$. quinquecirrha and Mnemiopsis leidyi have $96 \mathrm{~h} \mathrm{LC}_{50}$ s of $\leq 1.0 \mathrm{mg} \mathrm{l}^{-1}$ (E.D.H. as cited in Jordan et al. 1992) and, in laboratory predation and behavior experiments, C. quinquecirrha was quite tolerant of low oxygen conditions (Breitburg et al. 1994). However, C. quinquecirrha predation on anchovy eggs declines in concert with decreasing oxygen concentrations (Breitburg et al. 1997) indicating probable negative effects of oxygen depletion upon the predation capacity of $C$. quinquecirrha. It also is possible that medusae move into the upper layers of the water column when bottom-layer DO is low because their prey has migrated out of the bottom layer. This may be indicated by our observation that during Cruise 93-1 the proportional density of C. quinquecirrha in hypoxic bottom-water was significantly lower when ctenophore and other prey abundance was low than when abundance of ctenophores in the bottom layer was high $(t=11.94 \mathrm{p}=0.001)$. Furthermore, Figs. 6 , 8 \& 12 reveal a strong similarity between the proportional density of $C$. quinquecirrha and its copepod prey.

Highest densities of ctenophores in the bottom layer, as observed in this Patuxent River study, contrast with distributions in the Bay proper reported by Purcell et al. (1994), who observed highest densities in the sur- 
face layer. However, Purcell et al. (1994) sampled sites with bottom DO concentrations of $<1 \mathrm{mg} \mathrm{l}^{-1}$ and did not report any samples with ctenophore densities as high as those found in this study. Here, when ctenophores were in relatively low abundances, densities were lowest near-bottom. During Cruise 93-1, highest nearbottom densities of ctenophores were associated with lowest near-bottom densities of Chrysaora quinquecirrha, possibly indicating that ctenophore distributions were a reflection of predation pressure in surface and pycnocline layers (Cargo \& Schultz 1967, Miller 1974).

The decline in density of ctenophores, from an extremely high density in Cruise 93-1 to low density in cruise 93-2, cannot be explained simply by an increase in densities of predatory Chrysaora quinquecirrha, a linkage that has been argued in previous studies (Miller 1974, Feigenbaum \& Kelly 1984). Instead, our data suggest 2 possibilities, 1 of which respresents an interaction between DO and predation effects. Density of C. quinquecirrha did not increase significantly from Cruise 93-1 to Cruise 93-2 (93-1 = 5.9 $\pm 1.3 \mathrm{ml} \mathrm{m}^{-3}$; $93-2=6.7 \pm 1.7 \mathrm{ml} \mathrm{m}^{-3}$ ). It is possible that densities of C. quinquecirrha had increased substantially prior to Cruise 93-1 and that ctenophore densities were already declining during the 93-1 to 93-2 cruise periods. However, the severe drop in near-bottom DO from $>1 \mathrm{mg} \mathrm{l}^{-1}$ during Cruise 93-1 to $<0.5 \mathrm{mg} \mathrm{l}^{-1}$ during Cruise 93-2 (Table 1) may have forced ctenophores to migrate higher in the water column where C. quinquecirrha were in proportionally high densities, thereby increasing predation pressure on the ctenophores. Secondly, ctenophores could have been transported downriver, out of our sampling area, if they were confined mostly to above-pycnocline waters during this period of low bottom-water DO.

Densities of zooplankton that are potential prey of fish larvae decreased during episodes of bottom-layer hypoxia. Copepod nauplii declined significantly, but densities of copepods and copepodites (31\% decrease) and other zooplankton (24\% decrease), although apparently declining, had not decreased significantly. Roman et al. (1993) hypothesized that seasonal decreases in zooplankton abundance in mainstem Chesapeake Bay are partially due to bottom-layer hypoxia in summer.

Depth-distribution of all non-gelatinous zooplankton differed between low and high bottom-layer DO concentrations. For copepodites, densities were highest in the bottom layer when bottom-layer DO was $>2 \mathrm{mg} \mathrm{l}^{-1}$, but lowest there when bottom-layer DO was $\leq 2 \mathrm{mg} \mathrm{l}^{-1}$. This result is similar to that of Roman et al. (1993), who found that copepods in mainstem Chesapeake Bay were in greatest densities in the bottom layer when bottom-layer DO was $>1 \mathrm{mg} \mathrm{l}^{-1}$, but were nearly absent when bottom-layer DO was $<1 \mathrm{mg} \mathrm{l}^{-1}$. In our study, copepodites were never completely absent from bottom samples, even when DO was $<0.5 \mathrm{mg} \mathrm{l}^{-1}$. Copepods sampled under those oxygen conditions may have been dead or dying, because $24 \mathrm{~h}$ survival of Acartia tonsa, the most abundant copepod in our samples, declines sharply below $1 \mathrm{mg} \mathrm{l}^{-1}$ (Roman et al. 1993) and is near zero at $0.5 \mathrm{mg} \mathrm{l}^{-1}$ (Stalder \& Marcus 1997).

Changes in depth distribution of copepods and copepodites may be partly due to vertical migration in response to bottom-layer hypoxia. Behavioral plasticity of individual copepods with respect to depth-distribution is possible (Bollens \& Frost 1991). The lack of a strong overall decrease in whole water-column copepod densities combined with a significant decrease in the proportion of copepods in the bottom layer at low bottom-layer DO indicates that avoidance by copepods of hypoxic bottom water may have been a factor influencing vertical distribution. However, behavioral experiments conducted in stratified aquaria indicated that adult Acartia tonsa did not avoid oxygen concentrations $\leq 0.5 \mathrm{mg} \mathrm{l}^{-1}$ (Stalder \& Marcus 1997). Stalder \& Marcus (1997) hypothesized that depth distributions like those seen in Chesapeake Bay are primarily due to mortality of copepods in severely hypoxic bottom water. However, they also suggested that gradual development of bottom hypoxia, such as that which probably occurs at the sites we studied, and less precipitous DO gradients than those used in the laboratory, may lead to some avoidance not seen in their experiments. More study is needed to resolve the mechanisms leading to depletion of copepods in hypoxic bottom water.

Houde (1978) reported that a concentration of 100 micro- and meso-zooplankters $\mathrm{l}^{-1}$ could support high survival rates of bay anchovy larvae. We consistently found total mean zooplankton densities $>400 \mathrm{l}^{-1}$ and copepod densities (including nauplii) $>65 \mathrm{l}^{-1}$, except in hypoxic bottom-water, where fish larvae also were rare. It is not likely that starvation of fish larvae occurred because of low overall abundances of copepod nauplii during episodes of bottom-layer hypoxia. However, it is possible that the effect of bottom-layer oxygen concentration on the vertical distributions of zooplankton contributed to the relationship between near-bottom DO and the vertical distribution of fish larvae.

Bottom-layer DO did not significantly affect daynight differences in depth distributions of copepods in our study, as Roman et al. (1993) had reported, although the trends in our data were similar to their findings. When bottom-layer DO was high, densities of copepodites tended to be highest near the bottom during the day, but more evenly distributed at night. When daytime bottom-layer DO was low, densities of 
copepodites were low in the bottom layer. Although Roman et al. (1988) reported that in late summer, copepods, primarily Acartia tonsa, migrated from bottom waters to the surface of Chesapeake Bay during the night, we found only weak evidence of diel migration of copepods in our study, in which density of copepods increased at night in the surface layer, but in which a concurrent decrease in copepod density in the bottom layer was not observed.

Hypoxia may affect fish larvae through decreased growth and survival, limitation of habitat availability, and by altering predator-prey interactions. Our results indicate that vertical overlap of fish larvae with their predators and their prey may shift during episodes of bottom-layer hypoxia, potentially leading to important changes in predator-prey interactions and community structure. Effects of bottom-layer hypoxia on predator-prey interactions and predation mortality are complex (Breitburg et al. 1999); the effect of any disturbance in the physical habitat is likely to differ among species, leading to altered growth or predation mortality through changes in predator and prey distributions.

Acknowledgements. We thank J. Purcell and W. Boicourt for their reviews of our research and E. Perry for his statistical advice. Several people assisted on research cruises. We thank all, particularly M. Trice, J. Cleveland, J. MacGregor, C. Rilling, and T. Loher. L. Beaven, S. Dorsey, and L. Kellogg assisted in sample sorting. Research was funded by a US Department of Commerce, NOAA, University of Maryland Sea Grant award \#NA90AA-D-SG-063 to D.L.B. and E.D.H.

\section{LITERATURE CITED}

Barmawidjaja DM, Van der Zwaan GJ, Jorissen FJ, Puskaric S (1995) 150 years of eutrophication in the northern Adriatic Sea: evidence from a benthic foraminiferal record. Mar Geol 122:367-384

Bollens SM, Frost BW (1991) Diel vertical migrations in zooplankton: rapid individual response to predators. J Plankton Res 136:1359-1365

Breitburg DL (1991) Settlement patterns and presettlement behavior of the naked goby, Gobiosoma bosci, a temperate oyster reef fish. Mar Biol 109:213-221

Breitburg DL (1992) Episodic hypoxia in Chesapeake Bay: interacting effects of recruitment, behavior, and physical disturbance. Ecol Monogr 62:525-546

Breitburg DL (1994) Behavioral response of fish larvae to low dissolved oxygen concentrations in a stratified water column. Mar Biol 120:615-625

Breitburg DL, Steinberg N, DuBeau S, Cooksey C, Houde ED (1994) Effects of low dissolved oxygen on predation on estuarine fish larvae. Mar Ecol Prog Ser 104:235-246

Breitburg DL, Loher T, Pacey CA, Gerstein A (1997) Varying effects of low dissolved oxygen on trophic interactions in an estuarine food web. Ecol Monogr 67:489-507

Breitburg DL, Rose KH, Cowan JA Jr (1999) Linking water quality to survival of larval fishes: predation mortality of fish larvae in an oxygen-structured water column. Mar Ecol Prog Ser 178:39-54
Cargo D, Schultz L (1967) Further observations on the biology of the sea nettle and jellyfishes in Chesapeake Bay. Chesapeake Sci 8:209-220

Chesney EJ, Houde ED (1989) Laboratory studies on the effect of hypoxic waters on the survival of eggs and yolksac larvae of the bay anchovy, Anchoa mitchilli. In: Houde ED, Chesney EJ, Newberger TA, Vazquez AV, Zastrow CE, Morin LG, Harvey HR, Gooch JW (eds) Population biology of bay anchovy in mid-Chesapeake Bay. Center for Environmental and Estuarine Studies, Chesapeake Biological Laboratory, Solomons, (Final Report to Maryland Sea Grant Ref No [UMCEES] CBL 89-141), p 184-191

Cody RP, Smith JK (1991) Applied statistics and the SAS Programming language. North-Holland, New York

Cooper SR, Brush GS (1991) Long-term history of Chesapeake Bay anoxia. Science 254:992-996

Coutant CC (1985) Striped bass, temperature, and dissolved oxygen: a speculative hypothesis for environmental risk. Trans Am Fish Soc 114:31-62

Cowan JH Jr, Houde ED (1993) Relative predation potentials of scyphomedusae, ctenophores and planktivorous fish on ichthyoplankton in Chesapeake Bay. Mar Ecol Prog Ser 95:55-65

Crowder MJ, Hand DJ (1990) Analysis of repeated measures. Chapman \& Hall, New York

Detwyler R, Houde ED (1970) Food selection by laboratoryreared larvae of the scaled sardine Harengula pensacola (Pisces, Engraulidae) and the bay anchovy Anchoa mitchilli (Pisces, Engraulidae). Mar Biol 7:214-222

Dortch Q, Rabalais NN, Turner RE, GT Rowe (1994) Respiration rates and hypoxia on the Louisiana Shelf. Estuaries $17: 862-872$

Dovel WL (1971) Fish eggs and larvae of the upper Chesapeake Bay. Spec Rep Univ Md Nat Res Inst 4:1-171

Feigenbaum DK, Kelly M (1984) Changes in the lower Chesapeake Bay food chain in presence of the sea nettle Chrysaora quinquecirrha (Scyphomedusa). Mar Ecol Prog Ser 19:39-47

Houde ED (1978) Critical food concentrations for larvae of three species of subtropical marine fishes. Bull Mar Sci 28: 395-411

Houde ED, Lovdal JA (1984) Seasonality of occurrence, foods and food preferences of ichthyoplankton in Biscayne Bay, Florida. Estuar Coast Shelf Sci 18:403-419

Houde ED, Zastrow CE (1991) Bay anchovy. In: Funderburk, SL, Mihursky JA, Jordan SJ, Riley D (eds) Habitat requirements for Chesapeake Bay living resources, 2nd edn. Living Resources Subcommittee, Annapolis, MD (Chesapeake Bay Program), p 8.1-8.14

Howell P, Simpson D (1994) Abundance of marine resources in relation to dissolved oxygen in Long Island Sound. Estuaries 17:394-402

Jobling M (1994) Fish bioenergetics, 1st edn. Chapman \& Hall, London

Jordan S, Olson M, Stenger C, Mountford K, Batuik R (1992) Chesapeake Bay dissolved oxygen goal for restoration of living resources habitats. Report \# CBP/TRS 88/93. Maryland Department of Natural Resources, Annapolis, MD

Keister JE (1996) Habitat selection and predation risk: effects of low dissolved oxygen on zooplankton and fish larvae in Chesapeake Bay. MS thesis, University of Maryland, College Park, MD

Kolar CS, Rahel FJ (1993) Interaction of a biotic factor (predator presence) and an abiotic factor (low oxygen) as an influence on benthic invertebrate communities. Oecologia 95:210-219 
MacGregor J, Houde ED (1996) Onshore-offshore pattern and variability in distribution and abundance of bay anchovy Anchoa mitchilli eggs and larvae in Chesapeake Bay. Mar Ecol Prog Ser 138:15-25

Mackiernan, GB, Flemer DA, Nehlsen W, Tippie VA (1983) State of the Bay. Chesapeake Bay: framework for action. United States Environmental Protection Agency, Chesapeake Bay Program, Annapolis, MD, p 15-35

Magnuson JJ, Karlen DJ (1970) Visual observation of fish beneath the ice in a winter-kill lake. J Res Board Can 27: 1059-1068

Markle DF, Grant GC (1970) The summer food habits of young-of-the-year striped bass in three Virginia rivers. Chesapeake Sci 11:50-54

Miller RJ (1974) Distribution and biomass of an estuarine ctenophore population, Mnemiopsis leidyi (A. Agassiz). Chesapeake Sci 15:1-8

Milliken GA, Johnson DE (1984) Analysis of messy data, Vol 1. Designed experiments. Van Nostrand Reinhold, New York

Monteleone, DM, Duguay LE (1988) Laboratory studies of predation by the ctenophore Mnemiopsis leidyi on the early stages in the life history of the bay anchovy, Anchoa mitchilli. J Plankton Res 10:359-372

Norusis MJ (1993) SPSS advanced statistics user's guide. SPSS Inc, Chicago

Officer CB, Biggs RB, Taft JL, Cronin LE, Tyler MA, Boynton WR (1984) Chesapeake Bay anoxia: origin, development, and significance. Science 223:22-27

Olney JE (1983) Eggs and early larvae of the bay anchovy, Anchoa mitchilli, and the weakfish, Cynoscion regalis, in lower Chesapeake Bay with notes on associated ichthyoplankton. Estuaries 6:20-35

Petrosky BR, Magnuson JJ (1973) Behavioral responses of northern pike, yellow perch, and bluegill to oxygen concentrations under simulated winterkill conditions. Copeia $1: 124-133$

Pihl L, Baden SP, Diaz RJ (1991) Effects of periodic hypoxia on distribution of demersal fish and crustaceans. Mar Biol 108:349-360

Editorial responsibility: Jennifer Purcell (Contributing Editor), Cambridge, Maryland, USA
Pihl L, Baden SP, Diaz RJ, Schaffner LC (1992) Hypoxiainduced structural changes in the diet of bottom-feeding fish and Crustacea. Mar Biol 112:349-361

Purcell JE, Nemazie DA, Dorsey SE, Houde ED, Gamble JC (1994) Predation mortality of bay anchovy Anchoa mitchilli eggs and larvae due to scyphomedusae and ctenophores in Chesapeake Bay. Mar Ecol Prog Ser 114:47-58

Rabalais NN, Turner RE, Justic D, Dortch Q, Wiseman WJW Jr, Gupta BKS (1996) Nutrient changes in the Mississippi River and system responses on the adjacent continental shelf. Estuaries 19(2B):386-407

Rilling GC, Houde ED (1999) Regional and temporal variability in distribution and abundance of bay anchovy (Anchoa mitchilli) eggs, larvae and adult biomass in the Chesapeake Bay. Estuaries 22:1096-1109

Roman MR, Ashton KA, Gauzens AL (1988) Day/night differences in the grazing impact of marine copepods. Hydrobiologia 167:949-951

Roman MR, Gauzens AL, Rhinehart WK, White JR (1993) Effects of low oxygen waters on Chesapeake Bay zooplankton. Limnol Oceanogr 38:1603-1614

Sanford LP, Sellner KG, Breitburg DL (1990) Covariability of dissolved oxygen with physical processes in the summer Chesapeake Bay. J Mar Res 48:567-590

Shenker JM, Hepner DJ, Frere PE, Currence LE, Wakefield WW (1983) Upriver migration and abundance of naked goby (Gobiosoma bosci) larvae in the Patuxent River estuary, Maryland. Estuaries 6:36-42

Stalder LC, Marcus NH (1997) Zooplankton responses to hypoxia: behavioral patterns and survival of three species of calanoid copepods. Mar Biol 127:599-607

Taft JL, Taylor WR, Hartwig EO, Loftus R (1980) Seasonal oxygen depletion in Chesapeake Bay. Estuaries 3:242-247

Williamson CE, Stoeckel ME (1990) Estimating predation risk in zooplankton communities: the importance of vertical overlap. Hydrobiologia 198:125-131

Williamson CE, Stoeckel ME, Schoeneck LJ (1989) Predation risk and the structure of freshwater zooplankton communities. Oecologia 79:76-82

Submitted: November 8, 1999; Accepted: March 24, 2000

Proofs received from author(s): September 26, 2000 